\title{
Onshore-offshore seismic transect from the eastern Nankai Trough to central Japan crossing a zone of the Tokai slow slip event
}

\author{
Shuichi Kodaira ${ }^{1}$, Takashi Iidaka ${ }^{2}$, Ayako Nakanishi ${ }^{1}$, Jin-Oh Park ${ }^{1}$, Takaya Iwasaki ${ }^{2}$, and Yoshiyuki Kaneda ${ }^{1}$ \\ ${ }^{1}$ Institute for Research on Earth Evolution, Japan Agency Marine-Earth Science and Technology, \\ Showa-mach 3173-25, Kanazawa-ku, Yokohama 236-0001, Japan \\ ${ }^{2}$ Earthquake Research Institute, University of Tokyo, Yayoi 1-1-1, Bunkyo-ku, Tokyo 113-0032, Japan
}

(Received June 9, 2004; Revised February 19, 2005; Accepted May 17, 2005)

\begin{abstract}
In the summer of 2001, an onshore-offshore integrated seismic survey was carried out along a $485 \mathrm{~km}$ long profile crossing the eastern Nankai Trough and central Japan from the western edge of the Izu island arc. Seismic velocity and reflectivity images show ongoing subduction of repeated ridges. Two ridges are clearly resolved, the Paleo Zenisu-south ridge and -north ridge located between the Nankai Trough and central Japan. The two subducting ridges are $12 \mathrm{~km}$ thick by $40 \mathrm{~km}$ wide, and $20 \mathrm{~km}$ thick by $60 \mathrm{~km}$ wide, respectively. We propose that the north ridge may have prevented the eastward propagation of co-seismic slip during the 1944 earthquake due to strong coupling. Highly reflective subducting oceanic crust is imaged at $25-45 \mathrm{~km}$ depth beneath central Japan, and has a $2 \mathrm{~km}$ high dome structure at 30-40 km depth, indicating an even deeper ridge structure. This highly reflective subducted oceanic crust overlaps with the high Poisson's ratio zone imaged in a seismic tomography study. From these relations, we propose that the Tokai silent slip can be attributed to a high pore pressure zone, which significantly extends the conditionally stable region at the top of the subducted crust.
\end{abstract}

Key words: Nankai Trough, seismic imaging, subduction zone, slow slip, earthquake.

\section{Introduction}

The Nankai Trough is an active subduction zone where the Philippine Sea Plate subducts beneath the Japanese island arc. The convergence rate at the Nankai Trough is estimated to be $43-46 \mathrm{~mm} / \mathrm{yr}$ from earthquake mechanism studies with geological constraints (Seno et al., 1993). Recent continuous Global Positioning System (GPS) data have revealed an eastward decrease in the convergent rate along the Nankai Trough, from more than $50 \mathrm{~mm} / \mathrm{yr}$ in the west to less than $30 \mathrm{~mm} / \mathrm{yr}$ in the east (Heki and Miyazaki, 2001).

The Nankai Trough is a unique subduction zone because of the long historical record available that provides detailed information on the recurrence intervals and segmentation of the rupture zones of magnitude eight class earthquakes. The recurrence intervals of these events are estimated to be 100150 years, based on historical data that traces back to as early as the seventh century (Ando, 1975; Sangawa, 1998). Although the recurrence interval is fundamental information for understanding the earthquake process, the spatial distribution of slip is also represents an important because it shows systematic variations (e.g., Ando, 1975). All four segments shown in Fig. 1 have slipped with one or two successive events, except for the easternmost segment (segment $\mathrm{D}$, hereafter referred to as the Tokai segment). For example, the 1707 Hoei earthquake ruptured the entire Nankai Trough from the western end of the trough to the Tokai segment, whereas the 1854 Ansei earthquakes, which were

Copyright (c) The Society of Geomagnetism and Earth, Planetary and Space Sciences (SGEPSS); The Seismological Society of Japan; The Volcanological Society of Japan; The Geodetic Society of Japan; The Japanese Society for Planetary Sciences; TERRAPUB. two successive events (Ansei I and II) with a two day interval, ruptured pairs of segments: $\mathrm{C}-\mathrm{D}$ and $\mathrm{A}-\mathrm{B}$, respectively. The most recent events were the 1944 Tonankai and 1946 Nankai earthquakes. The 1946 Nankai earthquake ruptured segment $\mathrm{A}-\mathrm{B}$, which is the same segment as the Ansei II event, whereas the slip of 1944 Tonankai earthquake only extended across segment C. Consequently, the Tokai segment has not been ruptured since 1854 (Ando, 1975; Tanioka and Satake, 2001a; Kikuchi et al., 2003). Although much debated, several seismological studies have suggested a large earthquake may occur in the Tokai segment in the near future (Ando, 1975; Ishibashi, 1976).

Recent progress with modeling tsunami and seismic waveforms has significantly improved our knowledge of the co-seismic slip distribution of the 1944 Tonankai and 1946 Nankai earthquakes (Tanioka and Satake, 2001a, b; Baba et al., 2002; Cummins et al., 2002; Kikuchi et al., 2003; Baba et al., in press). According to Tanioka and Satake (2001b) and Baba et al. (2002), the slip of the 1946 event was not distributed uniformly in the segments, but extended over the entire area of segment B while only propagating in the deeper part of segment A. A study of sub-events of the 1946 event (Cummins et al., 2002) also showed that the rupture started offshore of the Kii peninsula near the updip end of segment B and propagated westward along the down-dip limit of segment A. For the slip distribution of the 1944 event, both tsunami wave (Tanioka and Satake, 2001a; Baba et al., in press) and seismic wave (Kikuchi et $a l ., 2003)$ modeling studies clearly showed that the slip of the 1944 event propagated across the entire segment C, with maximum slip at the center of the segment, but that no slip 


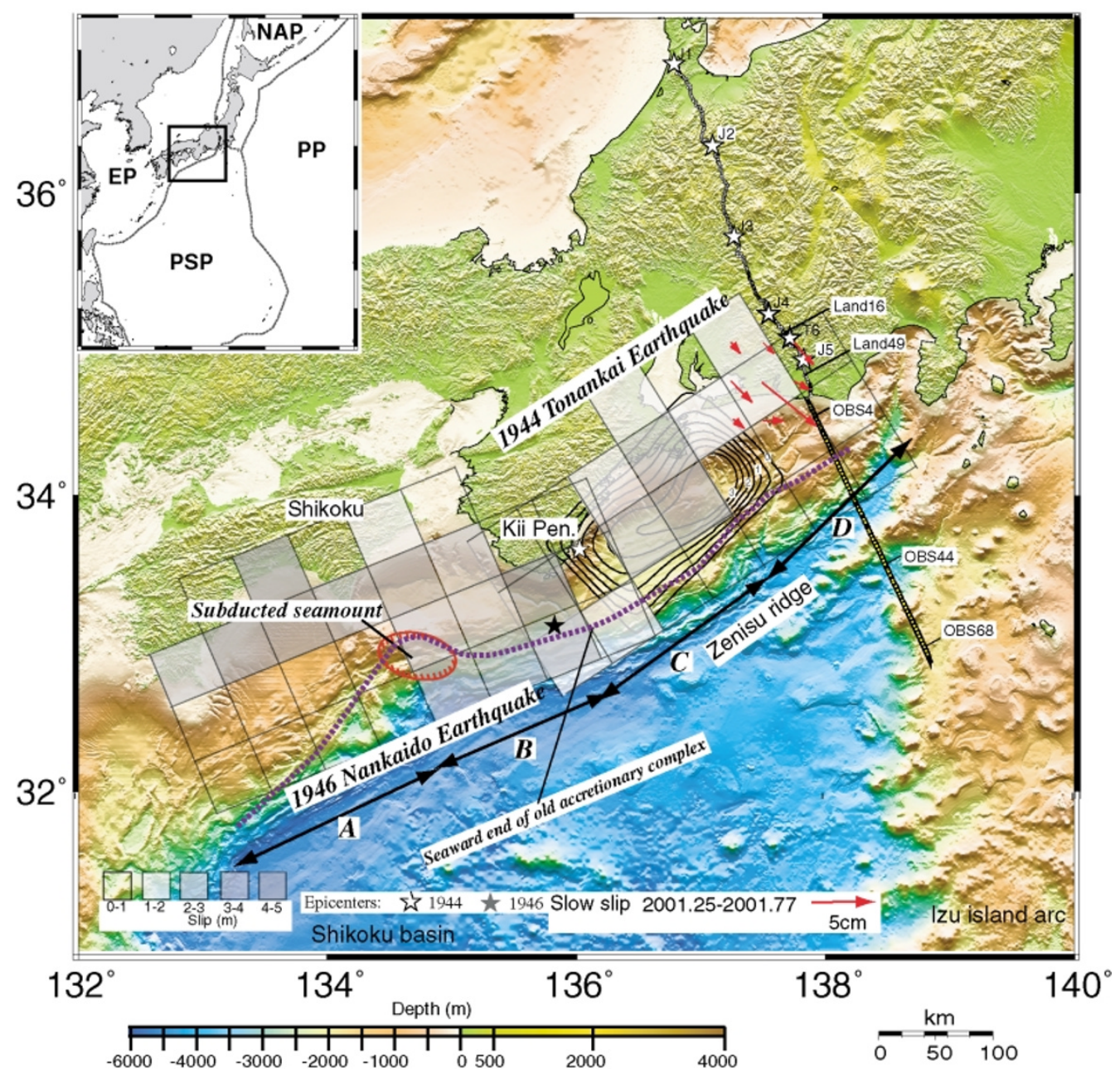

Fig. 1. Topographical map of central Japan and the location of the onshore-offshore wide-angle seismic profile. Stars and small circles indicate land explosions and seismic stations, respectively. The red arrows indicate estimated slow slip at the subduction interface (Ozawa et al., 2002). Four segments, A-D, indicate rupture zones complied from historic earthquake data (Ando, 1975). Grey squares indicate the slip distribution of the 1944 Tonakai and 1946 Nankai earthquakes determined from tsunami wave inversion (Tanioka and Satake, 2001b; Baba et al., in press). Black contours indicate the slip distribution of the 1944 Tonankai earthquake determined from strong ground motion data (Kikuchi et al., 2003). The dotted blue line indicates the seaward limit of the back stop of the present day accretionary system proposed by Nakanishi et al. (2003). Bathymetry data were compiled by the Hydrographic Department, Japan Maritime Safety Agency. NAP, North American Plate; PP, Pacific Plate; EP, Eurasian Plate; PSP, Philippine Sea Plate. The Kyusyu-Palau ridge and the Kinan seamount chain are located at the center and the western edge of the Shikoku basin, respectively. The area between $\mathrm{J} 2$ and $\mathrm{T} 6$ is referred to as the central mountain range.

extended into the Tokai segment, at least for the off-shore part of the Tokai segment.

An important result from these studies is that the maximum slip of both events is estimated to have been near $4 \mathrm{~m}$, which is comparable to the plate subduction rate for the inter-seismic period between the 1854 events and the 1944/1946 events. Geodetic studies using GPS data (Mazzotti et al., 2000; Heki and Miyazaki, 2001) obtained consistent results for the present inter-seismic period following the 1944/1946 events. Although they have a low resolution in the offshore part of the Nankai Trough because they used land GPS data, Mazzotti et al. (2000) concluded there is almost $100 \%$ inter-seismic coupling between 15-24 $\mathrm{km}$ depth at present in the central Nankai. In the deeper part of the inter-seismic coupled zone, recent dense GPS data have revealed a remarkable aspect of the slip in the Tokai segment. Ozawa et al. (2002) detected an aseismic slow slip, which corresponded to a magnitude of 6.8 , over 18 months in 2001 at $20-30 \mathrm{~km}$ depth in a $60 \times 60 \mathrm{~km}$ area in the Tokai segment.

Even though a spatial correlation between the segments of the slip zone and the forearc basins along the strike of the Nankai Trough has been suggested (Sugiyama, 1996; Wells et al., 2003), the cause of the segmentation had remained an unsolved question before precise subduction structures were recently obtained. There have been many efforts in imaging subduction structures around the Nankai Trough in central Japan since the 1980s. Around the up-dip limit of the co-seismic slip zones, seismic reflection studies have successfully imaged structures that were interpreted to be related to co-seismic/inter seismic slip processes. Seismic reflection images acquired around the deformation front showed that a decollement steps down to the top of subducted oceanic crust $30-40 \mathrm{~km}$ from the trough axis (Moore et al., 1990; Taira et al., 1991). This step down of the decollement is believed to be attributed to the up-dip end of the inter-seismic coupled zone; i.e. stable slip occurs along the decollement at depths shallower than the step down. Re- 
cently Park et al. (2002) also found from seismic reflection data, a steeply landward dipping splay fault at the up-dip end of the co-seismic slip region of the 1944 event. Baba et al. (in press) proposed that slip on the splay fault that reached the sea floor might have had a strong effect on the generation of tsunami.

Several wide-angle seismic studies have been carried out in the Nankai subduction zone (e.g., Kinoshita and Matsuda, 1989; Nishizawa and Suyehiro, 1989; Nishisaka et al., 1997; Nakanishi et al., 1998, 2002a, 2002b; Kodaira et al., 2000a; Iidaka et al., 2003). These mainly studies focused on imaging the geometry of the subducted crust as well as the overriding crust, however, they did not address the structural factors that control the segmentation of coseismic slip. As a result of advances in data acquisition techniques, important structural studies concerning the coseismic slip distribution of the 1944 and 1946 event were published recently (Kodaira et al., 2000b, 2002, 2003). At the boundary between segments A and B, Kodaira et al. (2000b) imaged a large subducted seamount, and Kodaira et al. (2002) proposed that co-seismic slip that started offshore of the Kii peninsula turned around at the landward foot of the subducted seamount due to locally strong coupling at the seamount; i.e., the subducted seamount functioned as a seismic barrier at the segmentation boundary.

Previous studies focused on the seismic velocity structures of either the offshore part or the onshore part of our profile (Kodaira et al., 2003; Iidaka et al., 2003). Structure at the oceanic crust-island arc transition has thus, not been resolved, even though this would provide key information for understanding the earthquake rupture process. The purpose of this study is, therefore, to map the crustal transect from the incoming Philippine Sea plate to central Japan, crossing the Tokai segment, by using newly processed onshore-offshore wide-angle seismic data. The resolution and uncertainties of the structural model are also discussed. The detailed implications of the transect for coseismic/inter-seismic slip are discussed in an accompanying paper (Kodaira et al., 2004).

\section{Tectonic Setting of the Eastern Nankai Subduc- tion Zone}

The incoming plate to the Nankai Trough, the northern part of the Philippine Sea Plate, is composed of several geological units: the Sikoku Basin, the Kyusyu-Palau ridge, the Kinan seamount chain, and the Izu-Bonin arc. The Sikoku Basin is a north-south elongated basin between the KyusyuPalau ridge and the Izu-Bonin island arc (Kobayashi et al., 1995). Rifting between the Kyusyu-Palau ridge and the IzuBonin island arc started at 30-27 Ma and continued until $15 \mathrm{Ma}$ with an E-W direction during the rifting stage and a NE-SW direction at the end of the spreading stage (Okino et al., 1999). The Kinan seamount chain formed from postspreading off-ridge activity along the spreading axis of the Shikoku Basin (Kobayashi et al., 1995; Sakamoto and Kim, 1999; Okino et al., 1999). En echelon seamount chains trending NE-SW (cross-arc seamount chains) are also recognized at the western edge of the Izu-Bonin arc. The Zenisu ridge is the northernmost member of these chains. On the basis of ages determined from rock samples, the cross-arc seamount chains were created after the spreading of the Sikoku Basin ceased (Ishizuka et al., 1998). These geological units on the incoming plate result in an age variation in the subducting plate along the Nankai Trough; i.e., it generally becomes older west and east of the spreading center, which is located off the Kii peninsula. It has been proposed on the basis of several seismological studies that the variation in the age of the subducted oceanic crust might contribute to the variation in seismic activity along the Nankai Trough (e.g., Sugi and Uyeda, 1984; Shiono and Sugi, 1985).

The eastern part of the Nankai Trough has a complicated tectonic regime compared to the western part of the trough. This is because the subducting crust has been affected by the volcanic activity of the Izu-Bonin arc and is influenced by the collision and subduction of the Izu-Bonin arc under central Japan. Several thrust faults have been traced in seismic images of the southern flank of the Zenisu ridge (Aoki et al., 1982; Mazzotti et al., 2002; Takahashi et al., 2002). These faults have been proposed to be the result of the collision and to have resulted from crustal shortening/thickening processes. On the basis of this, Mazzotti et al. (2002) suggested that the Zenisu ridge originally formed from crustal shortening/thickening processes at an old fracture zone. However, this idea cannot explain volcanic and petrological observations. As described above, the rock samples collected at the Zenisu ridge indicate volcanic activity after the spreading of the Shikoku basin ceased, and suggest the same origin as the cross-arc seamout chains at the western edge of the Izu-Bonin arc (Yuasa, 1985; Nakamura et al., 1987; Ishizuka et al., 1998). It is more likely, from both seismic and petrological evidence, that the northernmost part of the cross-arc seamount system, the Zenisu ridge, formed from volcanic activity and was overprinted by the crustal shortening and thickening.

Another member of the cross-arc seamount system is proposed to have been subducted beneath the Tokai segment. Lallemand et al. (1992) suggested that the steeper slope of the accretionary prism in the Tokai segment is related to subduction of a ridge that is similar to the Zenisu ridge, based on a comparison with analog sand-box modeling. Le Pichon et al. (1996) supported this idea through modeling gravity and magnetic data. They identified a large magnetic body landward of the trough, and named it the Paleo-Zenisu ridge. Le Pichon et al. (1996) also considered that the subducted Paleo-Zenisu ridge may be a key structure controlling earthquake processes in the Tokai segment.

\section{Data Acquisition}

From August to September 2001, the Japan Marine Science and Technology Center (JAMSTEC), in cooperation with the University of Tokyo, acquired integrated onshoreoffshore wide-angle seismic data along a $485 \mathrm{~km}$ profile from the western edge of the Izu-Bonin arc to the coast of the Japan Sea, crossing the Nankai Trough and central Japan (Fig. 1). Mutichannel seismic (MCS) reflection data were also acquired at a part of the profile (Fig. 1).

Along the offshore part of the profile seventy OBSs were deployed with spacing of approximately $3 \mathrm{~km}$ for acquiring wide-angle seismic data. Three of the OBSs 
(a)
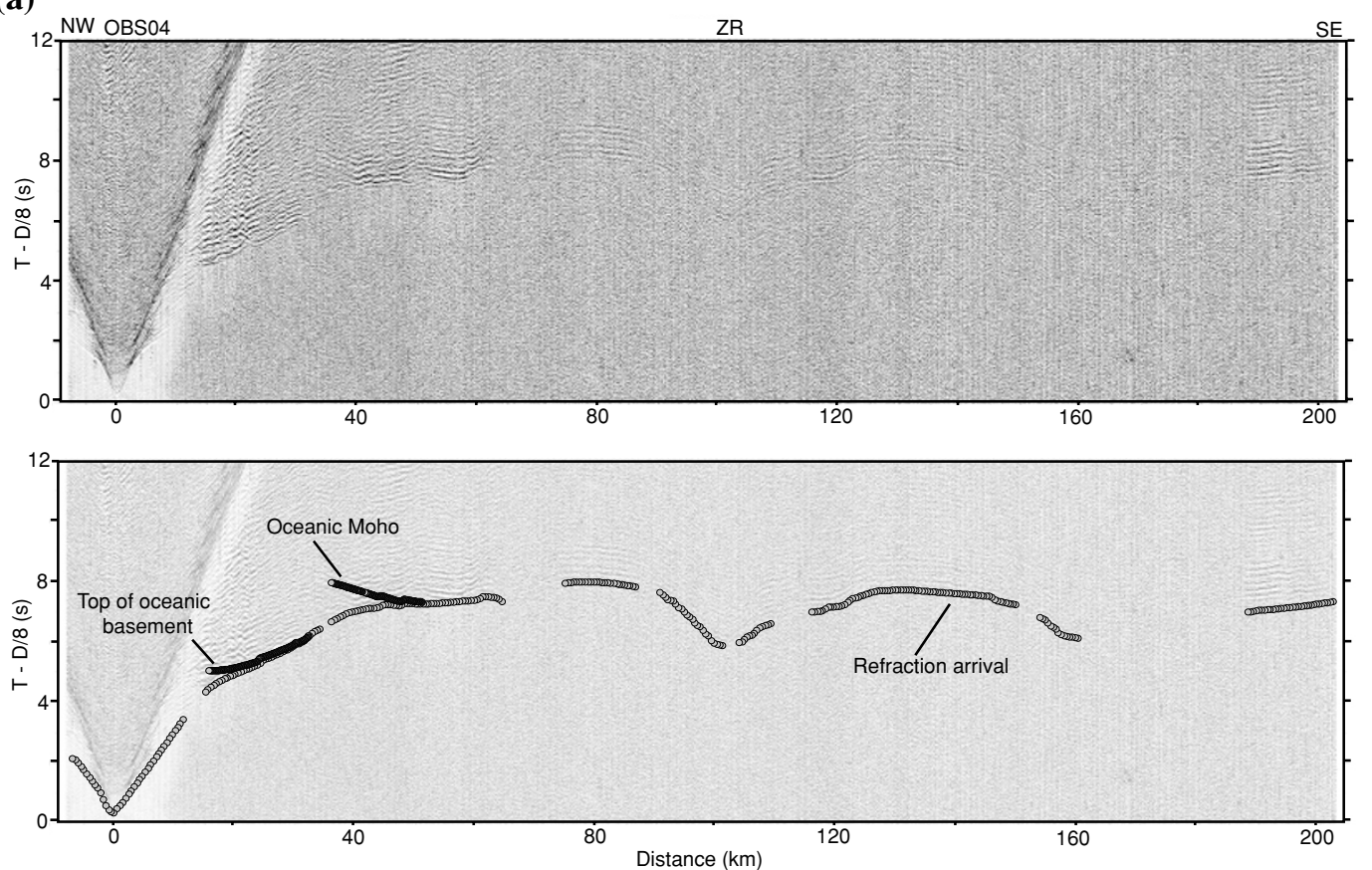

(b)
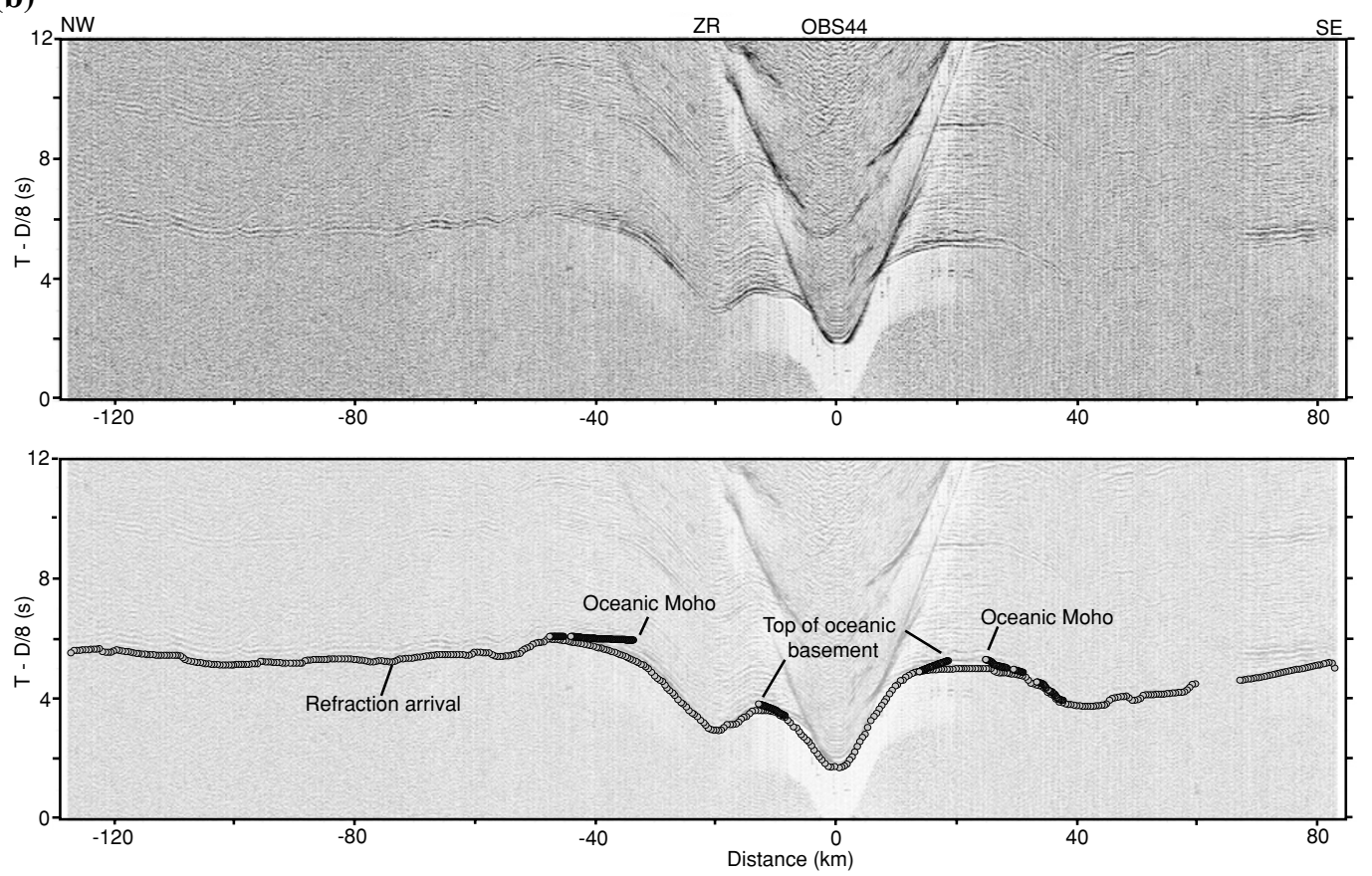

Fig. 2. Examples of OBS record sections (upper panels) and calculated travel times from the final model superimposed on the observed data (lower panels). A bandpass filter $(5-20 \mathrm{~Hz})$, a predictive deconvolution filter and an automatic gain control of $4 \mathrm{~s}$ were applied. The reduction velocity is 8 $\mathrm{km} / \mathrm{s}$. Horizontal axes indicate offset distance from the OBS. Only prominent reflection phases as well as first arrival refraction phases modeled in this study are plotted in the lower panels. (a) OBS04, (b) OBS44, (c) OBS68. ZR; location of the Zenisu ridge.

were not recovered (OBS21, OBS31, OBS47) and two of them did not recorded signals (OBS2, OBS51) because of mechanical troubles. The OBS $(4.5 \mathrm{~Hz}$ three-component gimbal-mounted geophone and hydrophone, continuous 16bit digital recording with $100 \mathrm{~Hz}$ ) used were designed by Kanazawa and Shiobara (1994) and Shinohara et al. (1993). For deep penetration of seismic energy, a large volume air gun array (197 L) was fired every $100 \mathrm{~m}$ by JAMSTEC's research vessel Kaiyo. We acquired MCS data using a seismic system mounted on another JAMSTEC research ves- sel, Kairei (156-channel streamer with $25 \mathrm{~m}$ group spacing, $50 \mathrm{~m}$ shot interval using the same volume of air gun array described above).

For the onshore part of the profile, six explosions were shot. Charge sizes were $500 \mathrm{~kg}$ at $\mathrm{J} 1, \mathrm{~J} 2, \mathrm{~J} 3, \mathrm{~J} 4$ and J5, and $100 \mathrm{~kg}$ at T6. A total of 391 seismic stations were deployed along the $262 \mathrm{~km}$ profile. 328 of the stations had a vertical component sensor $(2.2 \mathrm{~Hz})$, while the 63 stations deployed at the southern part of the profile had a threecomponent sensor $(4.5 \mathrm{~Hz})$. The average spacing of the 
(c)
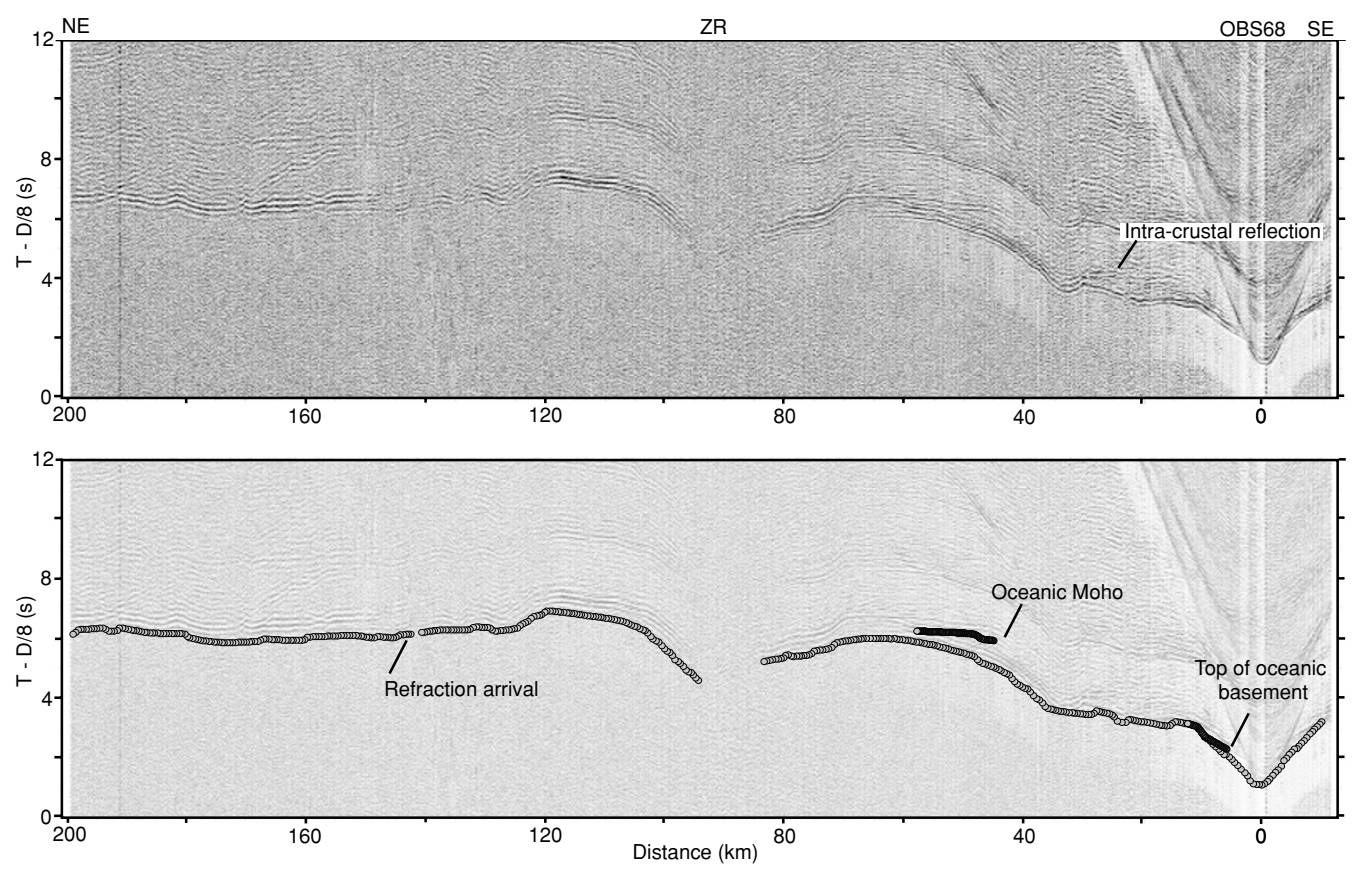

Fig. 2. (continued).

stations was $669 \mathrm{~m}$. Sampling rate was $100 \mathrm{~Hz}$ at both types of stations. Both the land stations and the OBSs recorded signals from the land explosions, whereas signals from the air gun array were recorded by the OBSs and some of the land stations deployed at the southern part of the onshore profile (approximately between $\mathrm{J} 4$ and the coast line). In our previous studies (Iidaka et al., 2003; Kodaira et al., 2003), we processed the onshore and the offshore parts of the wide-angle data separately. In this study, we have newly combined the onshore-offshore wide-angle data, including land recordings of the air gun shots. These new data allow us to image the onshore-offshore boundary, and to resolve deeper structures.

4. Processing and Description of Wide-Angle Seismic Data

\subsection{Data processing}

The onshore-offshore wide-angle seismic survey provides three types of record sections depending on the shotreceiver pairs, i.e., a conventional type of offshore receiver gather, a conventional type of the onshore shot gather, and a receiver gather of air gun signal recorded by the land stations. The third type of record was only obtained for land stations deployed between approximately J4 and the coast line, due to limitations of the recording memory. This type of data is a critical for mapping the seismic structures around the coastline, and had been missing from the previous studies that considered the onshore and offshore data separately (Iidaka et al., 2003; Kodaira et al., 2003). We also paid attention to the major secondary arrivals, which were not used in the previous studies (Kodaira et al., 2003). These provide useful information for determining the crustal thickness more accurately.

For the signal from the airgun, we applied simple prepro- cessing including a 5-20 Hz band-pass filter to increase the signal to noise ratio, a predictive deconvolution filter to reduce reverberation after strong first and later arrivals, and an $4 \mathrm{~s}$ window automatic gain control to make the first arrivals clear when we picked arrival times. For the land explosion data, we only applied the $5-20 \mathrm{~Hz}$ band-pass filter and the $4 \mathrm{~s}$ window automatic gain control.

\subsection{Air gun shot recorded by OBSs}

Examples of the OBS record sections are shown in Fig. 2. The quality of the data is generally high, except for the data from the OBSs located around the Zenisu ridge (OBS3639). Clear first arrivals are observed up to the end of the profile for most of the OBSs. The long offset first arrivals provide important information for deep structural imaging by wide-angle seismic surveys. The topography of the Zenisu ridge strongly affects the apparent velocity of the first arrivals in the middle of the profile; i.e. the $2 \mathrm{~s}$ forward bending of the travel time over a $30 \mathrm{~km}$ wide corresponds to the Zenisu ridge.

Due to the complicated topography and underground structure, the character of the observed sections strongly varies along the profile. For example, the data for the northern part of the profile are characterized by slower apparent velocity, less than $8 \mathrm{~km} / \mathrm{s}$, phases traced to $60 \mathrm{~km}$ offsets (Fig. 2(a)), whereas in the middle of the profile slower apparent velocity phases (less than $8 \mathrm{~km} / \mathrm{s}$ ) are only observed to $20 \mathrm{~km}$ offsets (Fig. 2(b)). This implies a significant thickening of the crust to the north. The data for the southern part also show a longer observable range for the crustal refraction phase (i.e. apparent velocity slower than $8 \mathrm{~km} / \mathrm{s}$ ), however the apparent velocity of the crustal phase (10-60 $\mathrm{km}$ offset in Fig. 2(c)) is faster than the crustal phase observed in the northern part (Fig. 2(a)). This may not only be affected by topography but can also be attributed to crustal 
(a)
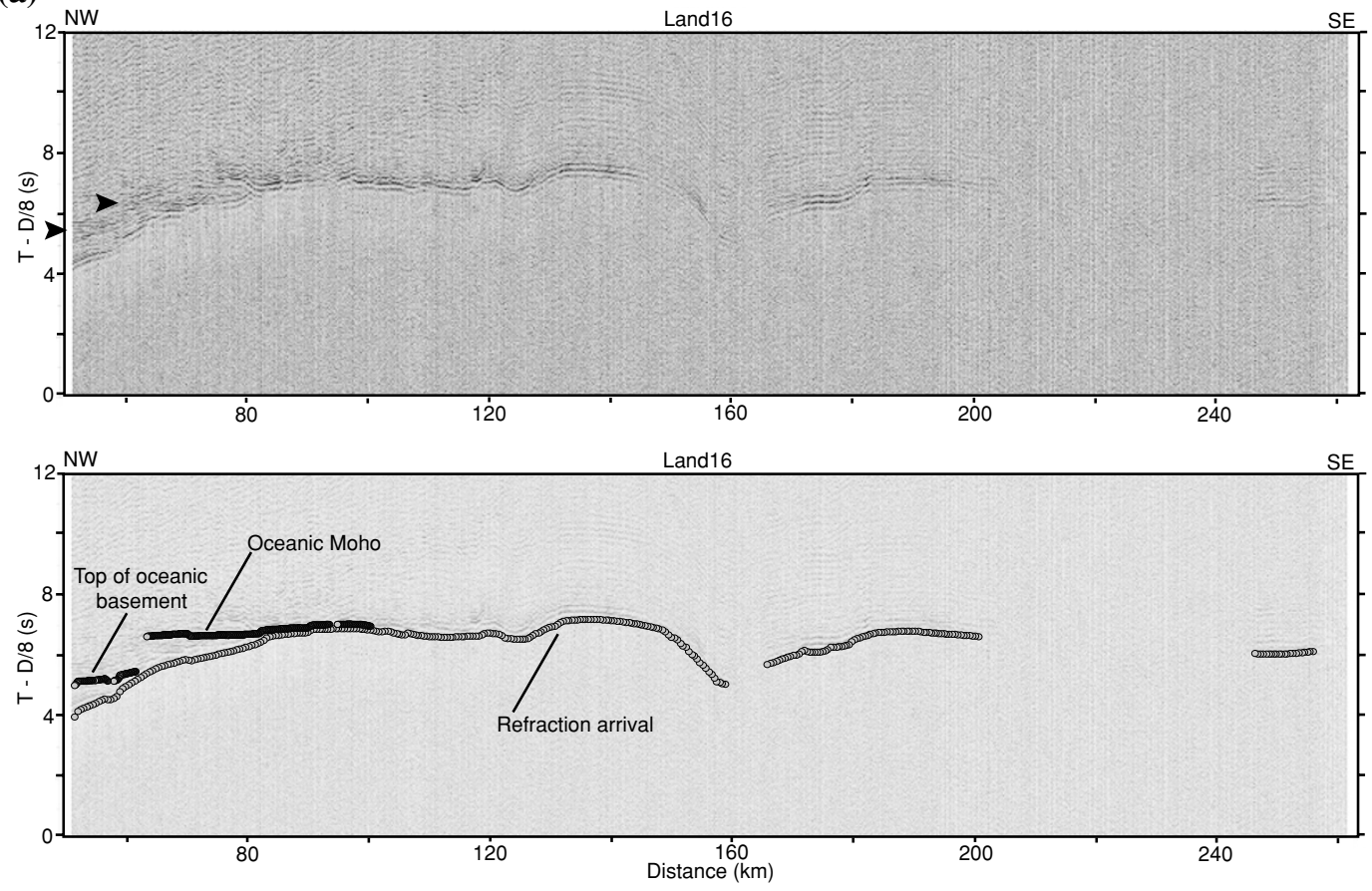

(b)

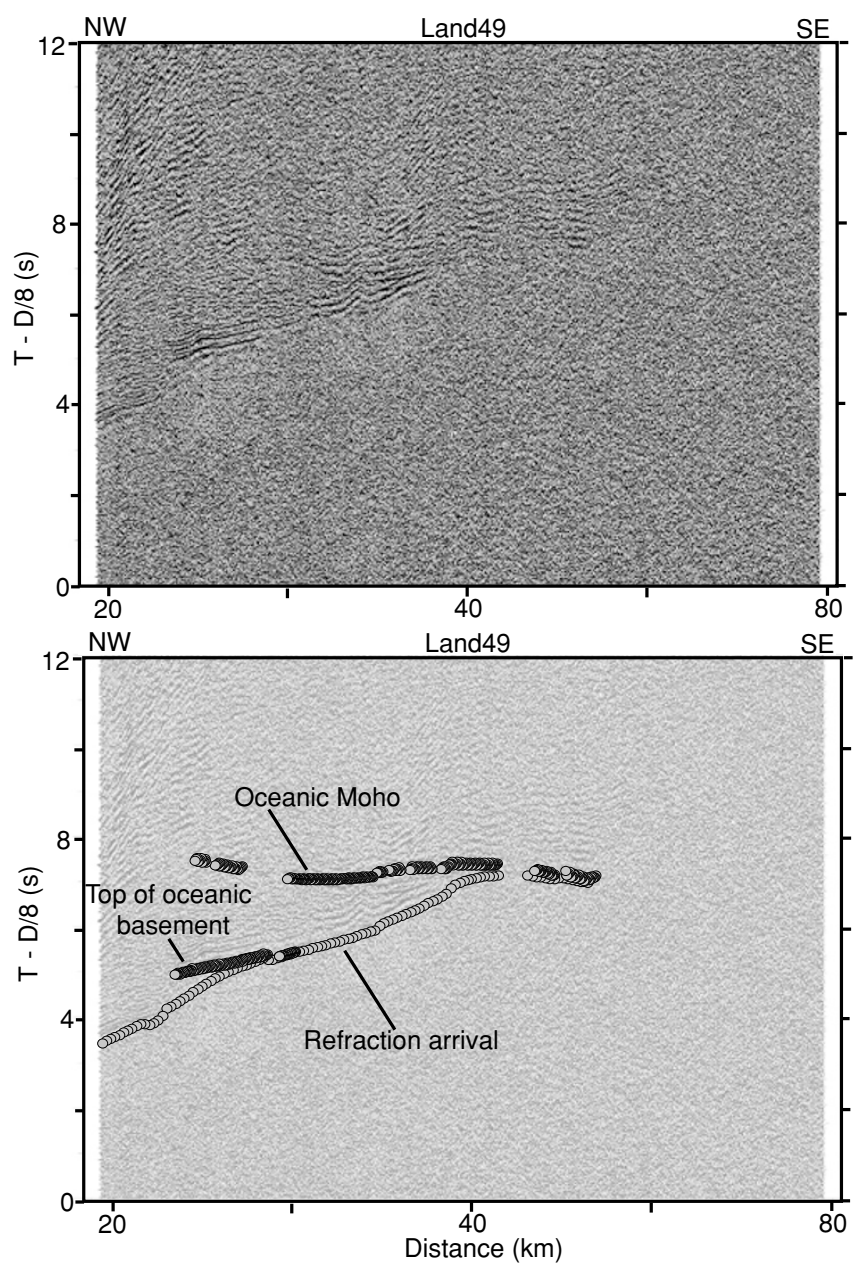

Fig. 3. Examples of record sections from land stations (upper panels) and calculated travel times from the final model superimposed on the observed data (lower panels). A bandpass filter $(5-20 \mathrm{~Hz})$, a predictive deconvolution filter and an automatic gain control of $4 \mathrm{~s}$ were applied. The reduction velocity was $8 \mathrm{~km} / \mathrm{s}$. Horizontal axes indicate offset distance from the station. Only prominent reflection phases as well as first arrival refraction phases modeled in this study are plotted in the lower panels. (a) Land16, (b) Land49. 
(a)
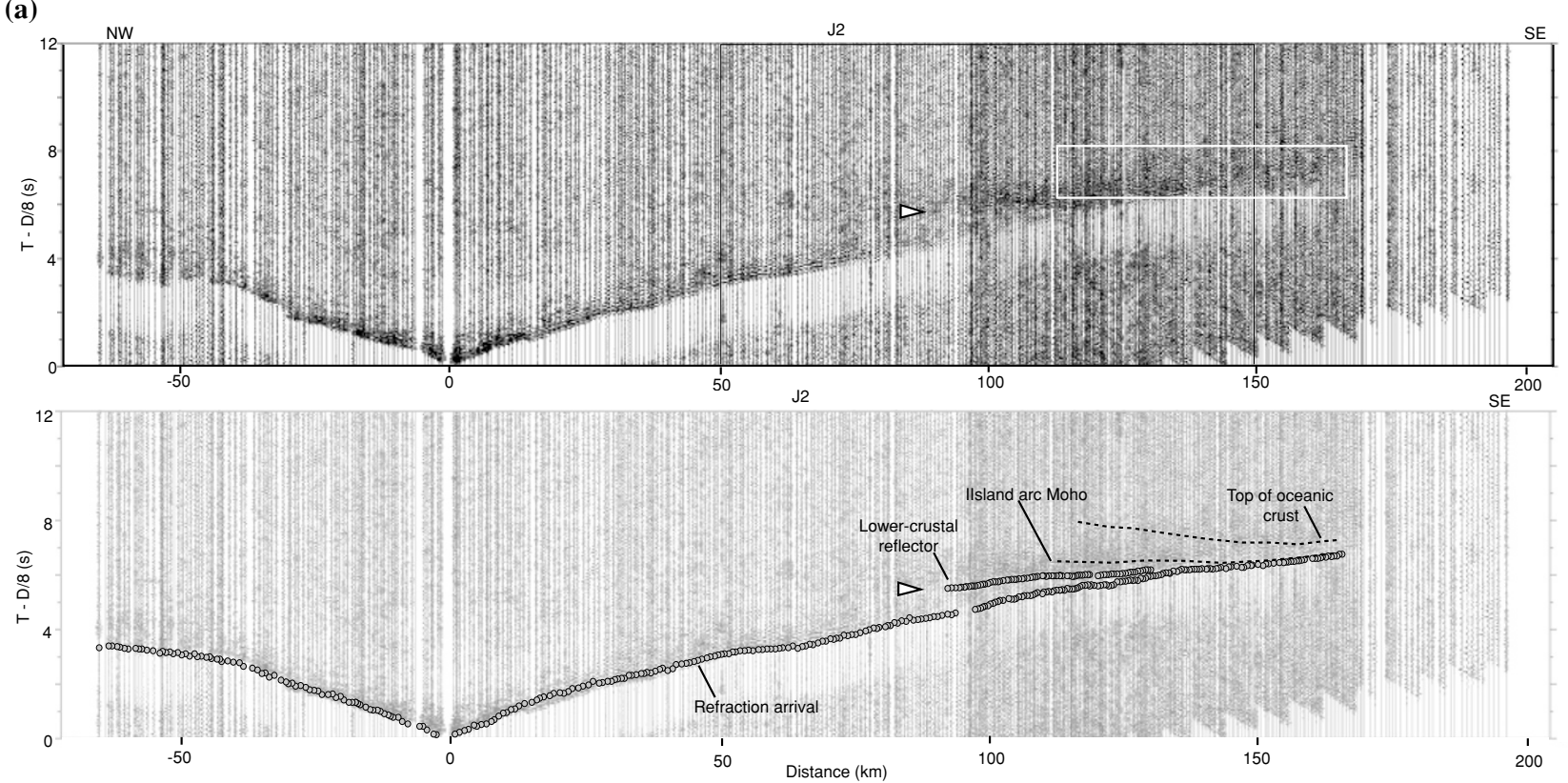

(b)
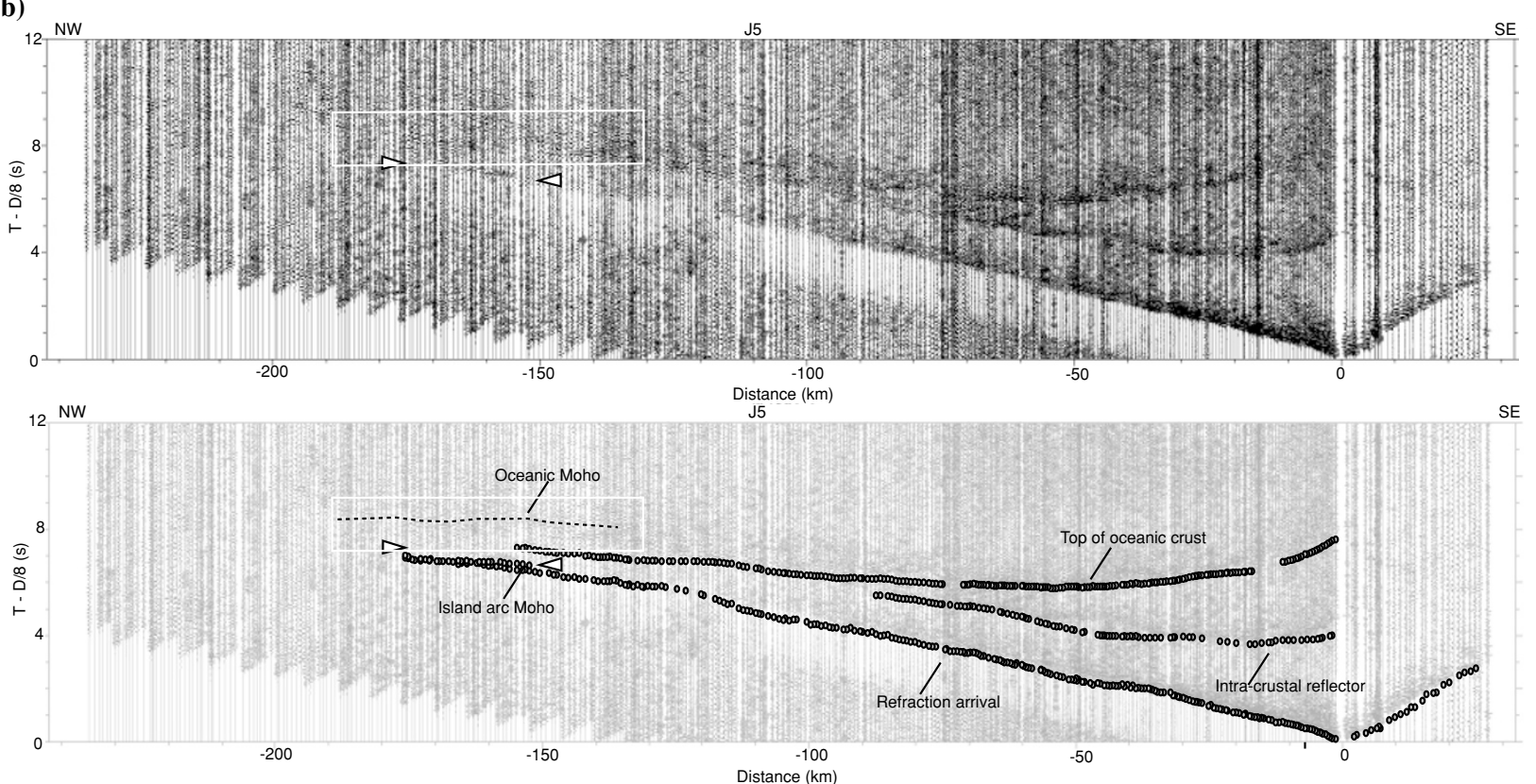

Fig. 4. Examples of record sections of land explosions (upper panels) and calculated travel times from the final model superimposed on the observed data (lower panels). A bandpass filter $(5-20 \mathrm{~Hz})$, and an automatic gain control of $4 \mathrm{~s}$ were applied. The reduction velocity was $8 \mathrm{~km} / \mathrm{s}$. Horizontal axes indicate offset distance from the station. The calculated travel times are plotted as circles on traces on which the observed travel times were picked. Only prominent reflection phases as well as first arrival refraction phase modeled in this study are plotted in the lower panels. (a) J2. Calculated travel times of reflections from the Island arc Moho and the top of the subducted crust are plotted as dotted lines, because the travel times of those phases were not picked due to unclear onsets (see the observed data in the white rectangular). (b) J5. Calculated travel times of reflections from the Moho of the subducted oceanic crust are plotted as dotted lines, because the travel times of this phase were not picked due to unclear onsets (see the observed data in the white rectangular).

material with a slower $P$-wave velocity in the northern part compared to the southern part.

Phase identification is necessary for conventional layerstripping modeling, however, the strong variations in the first arrivals made this difficult. Therefore, as described below, we used a tomographic modeling approach that does not require phase identification of the first arrivals to obtain a seismic velocity image.

Clear reflection phases can also be recognized (Fig. 2). The most prominent reflection phase is the last reflection phase observed (e.g. 40-60 km offset in Figs. 2(a) and 2(c)). Another reflection phase can be recognized at nearer offsets, 15-40 km offset in Fig. 2(a). There, two phases can be continuously observed across the profile (e.g., Fig. 2), except around the Zenisu ridge. According to previous wideangle studies of the eastern Nankai trough (e.g. Nakanishi et al., 1998, 2002a; Kodaira et al., 2003), strong acoustic impedance contrasts, which may produce strong reflection phases, are obtained for the bottom and the top of the oceanic crust. We thus interpreted the two observed con- 


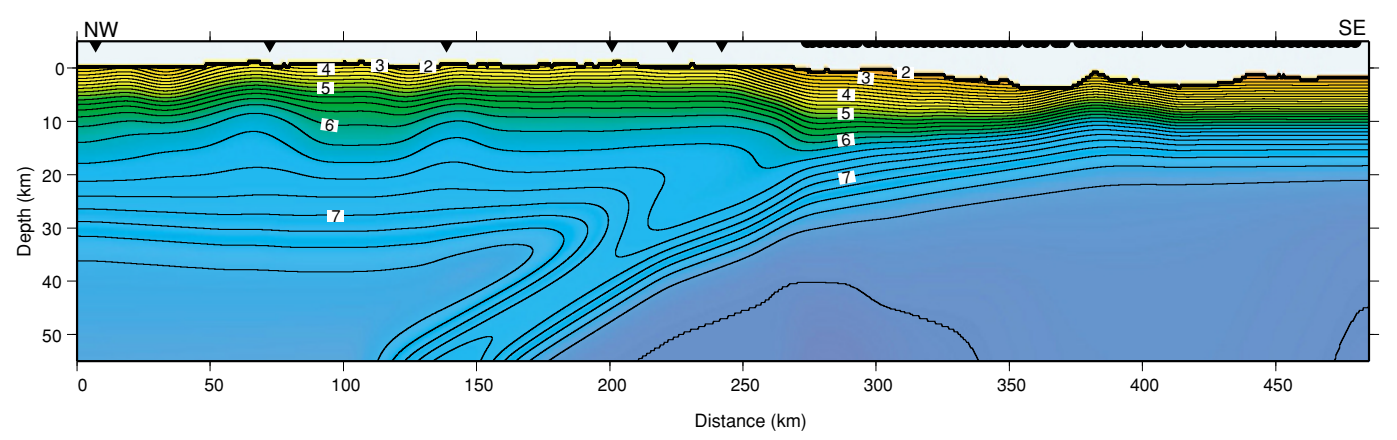

Fig. 5. Initial model for the first arrival refraction tomography. This model was constructed from results of previous studies (Iidaka et al., 2003; Kodaira et al., 2003). Vertical exaggeration is $2: 1$.

tinuous reflection phases as reflections from the bottom and top of the oceanic crust. In addition to these two reflection phases, reflection phases interpreted to be from locally distributed reflectors in the crust are also observed, e.g., $30 \mathrm{~km}$ offset at OBS68 (Fig. 2(c)), however, we did not model the locally observed reflection phases in this study.

\subsection{Air gun shot recorded by land stations}

The air gun shots were observed at the land stations deployed in the southern part of the onshore profile (Fig. 1). As shown by previous onshore-offshore studies (e.g. Kodaira et al., 2003), the onshore recording of the offshore shots provides useful data for revealing structures beneath coastal areas, which are usually missing when imaging uses only onshore or offshore data independently. The data quality differs from station to station because of a difference in background noise mainly caused by human activity. The southernmost part of the onshore profile had to be situated in a highly populated region and the quality of the data there is poor.

The first arrivals can be traced to more than $250 \mathrm{~km}$ offset on higher quality sections (e.g., Fig. 3(a)). First arrivals showing an apparent velocity of nearly $8 \mathrm{~km} / \mathrm{s}$ are observed at larger offsets in the onshore data than in the offshore OBS data for near the coastline. For example, these arrivals are observed at further than $90 \mathrm{~km}$ offset in Fig. 3(a), but at only $50 \mathrm{~km}$ offset in Fig. 2(a). This implies that the crustmantle boundary (Moho) becomes deeper toward the land.

We also observed the two prominent reflection phases (Fig. 3) on the onshore data. These phases are interpreted as reflections from the top and bottom of the oceanic crust on the basis of a continuation from the OBS data. The reflections from the bottom of the crust have a similar amplitude character to the OBS data, whereas the reflections from the top of the oceanic crust are even clearer in the land station data (Fig. 3(b)).

\subsection{Land explosions recorded by land stations}

All land explosion data show clear first arrivals up to 150-200 km offsets (Fig. 4). Most of the first arrivals are interpreted as crustal refraction arrivals, with apparent velocities of less than $8 \mathrm{~km} / \mathrm{s}$. Only the arrivals at offsets farther than $150 \mathrm{~km}$ show apparent velocities of nearly 8 $\mathrm{km} / \mathrm{s}$ (Fig. 4(b)). This indicates, from comparison with the OBS data, a significant thickening the crust toward the land.

The most notable features of the land explosion data are the strong reflection phases observed from nearly zero off- set in the J5 section (Fig. 4(b)). The two reflection phases appear to have a similar amplitude in Fig. 4(b) because of the amplitude correction (4 $\mathrm{s}$ window automatic gain control), however, a true amplitude section shows that the later reflection arrivals are stronger than the faster reflection phase. By comparing the travel time of the later reflection arrival to the reflection arrivals observed at Land49 (Fig. 3(b)), we interpreted the later phase as the reflection from the top of the subducted (landward dipping) oceanic crust beneath the land, i.e., with a reduced travel time of $6 \mathrm{~s}$ and $5 \mathrm{~s}$ at $30 \mathrm{~km}$ offset in $\mathrm{J} 5$ section and Land 49 section, respectively. Thus, the faster reflection phase in the J5 section is interpreted as the reflection from the overriding plate (an intra-crustal reflection). Additional weak reflection phases, which are interpreted as intra-crustal reflections, are also recognized. For example, the phase observed from $90 \mathrm{~km}$ offset at $7 \mathrm{~s}$ reduced travel time on Fig. 4(a).

\section{Modeling Procedure}

We present a seismic velocity and a seismic reflectivity image obtained from the combined the onshore-offshore wide-angel seismic data and the MCS data. First arrival refraction tomography was applied for mapping the seismic velocity image. Forward modeling the observed prominent reflection phases was also used to plot the geometries of the incoming subducting crust, the bottom of the island arc crust, and intra-crustal reflectors. For the reflector mapping, the velocity structure was fixed as it was obtained from the refraction tomography, i.e., reflectors are mapped as floating reflectors on the continuous velocity structure.

An advantage of refraction tomography compared with conventional layer stripping modeling is that phase identification of the observed refraction phases is not required. In this sense the tomographic approach is considered to be more objective and robust (Zelt et al., 2003). However, the final model strongly depends on the initial model. Therefore, an appropriate initial model must be selected. A bestfitting laterally homogeneous (1-D) model (e.g., Zelt et al., 2003) or a model based on information obtained from previous studies (e.g. Kodaira et al., 2000b) are commonly used as initial models. The initial model used in this study was constructed by combining, simplifying and smoothing the results of the previous studies that used the onshore data (Iidaka et al., 2003) and the offshore data (Kodaira et al., 2003) (Fig. 5). 

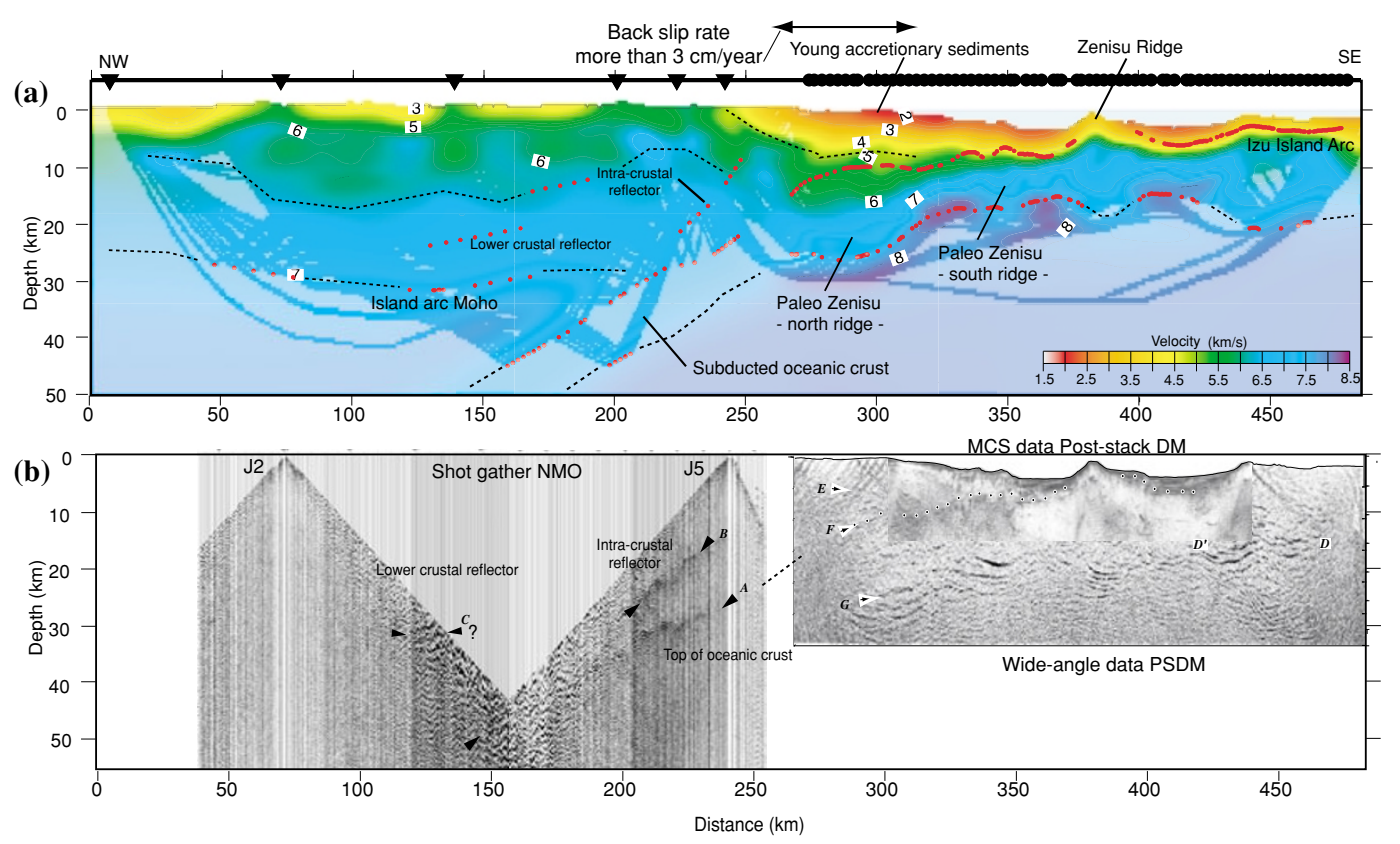

Fig. 6. Seismic velocity and reflectivity images modified after Kodaira et al. (2004) (a) Seismic velocity image with reflection points (red dots) of prominent reflections. Black dotted lines show interpretation of the crustal block. The lighter colored regions indicate no seismic rays sampled. Triangles and circles on the top of the frame indicate locations of the land explosions and OBSs, respectively. Horizontal axis is measured from the northern end of the profile. An area indicating back slip rate of more than $3 \mathrm{~cm} /$ year (Sagiya, 1999) is shown at the top of the figure. (b) Seismic reflectivity image. The offshore part of the section is modified from Kodaira et al. (2003). The onshore part of the section was created from NMO corrected sections of J2 and J5. Reflectors A, top of the subducted crust; B, intra-crustal reflection interpreted as a deeper extension of the Median Tectonic Line (Sato et al., 2002); C, Island arc Moho; D-D', top of the middle crust of Izu island arc; E bottom of the Neogene-Quaternary accretionary prism, the seaward termination of the reflector E is not well imaged; F, top of the subducted crust; G, bottom of the subducted crust. Vertical exaggeration is $2.2: 1$.

The software package used for the refraction tomography was GeoCT-II, which is based on the algorithm of Zhang et al. (1998). This software allowed both the forward modeling of refraction and reflection travel times, and an inversion of refraction travel times for constructing a velocity image using a uniform grid of velocity nodes. For travel time and ray path calculations, this software applies a wave front method (Zhang and Toksöz, 1998) employing graph theory that allows only straight rays within a cell of constant slowness (Zhang et al., 1998). For calculation of the reflection travel time, the travel time calculation mentioned above was modified following Moser (1991) and Hole and Zelt (1995). In the inversion step, a regularized nonlinear inversion was applied for reconstructing velocities. Details of the travel time calculations and the inversion are described by Zhang et al. (1998).

In our case, we used $0.5 \times 0.5 \mathrm{~km}$ grids for both forward and inversion calculations. All observed refraction and reflection travel times of prominent reflections were picked with an uncertainty of up to $0.15 \mathrm{~s}$, depending on the signal to noise ratio. The maximum uncertainties for refractions and reflections are $0.1 \mathrm{~s}$ and $0.15 \mathrm{~s}$, respectively. An iteration of the inversion was stopped when the root mean square of the travel time residual became smaller than the observed uncertainty. All picked travel times were used for modeling the reflection phases, whereas one of every three picks was used for the refraction travel time inversion due to a limitation of the software.

A reflectivity image for the entire offshore profile was obtained in our previous study (Kodaira et al., 2003). This image was a combined section of post-stack depth migration sections of MCS data and the pre-stack depth migration of OBS data. In this paper, for obtaining the reflectivity image of the offshore profile, we applied only a normal move out (NMO) for two shot gathers of the land explosion where clear reflection phases were identified. An average one dimensional velocity structure around the shot points was used for the NMO.

\section{Seismic Velocity and Reflectivity Images and Implications for Co-Seismic/Inter-Seismic Slip \\ 6.1 Deep seismic velocity and reflectivity images from wide-angle seismic data}

Figure 6 shows the seismic velocity image with reflectors obtained from the wide-angle reflection travel times. As described in the previous section, we only modeled prominent reflection phases, which include the reflections from the top and bottom of the subducting oceanic crust, the island arc Moho and intra-crustal reflectors (Fig. 6). The travel time residuals calculated from the final model are shown in Fig. 7. In this figure, we plot the mean travel time residuals of each phase group calculated for each OBS at its position, as it is not practical to show all travel time curves for all OBSs and land stations. From these plots it can be recognized that most of the residuals are less than the maximum ranges of the uncertainties of the observed data (e.g. $+/-0.1 \mathrm{~s}$ for refraction arrivals and $+/-0.15 \mathrm{~s}$ for reflection arrivals). The residuals of the reflections from the top of the oceanic crust between $370-420 \mathrm{~km}$ show larger misfits than other parts. This misfit may result from a misin- 
(a)
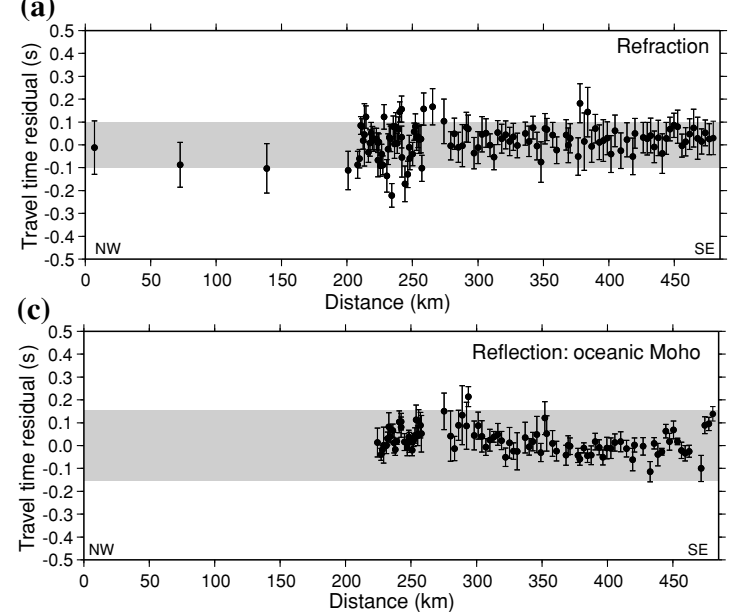

(b)
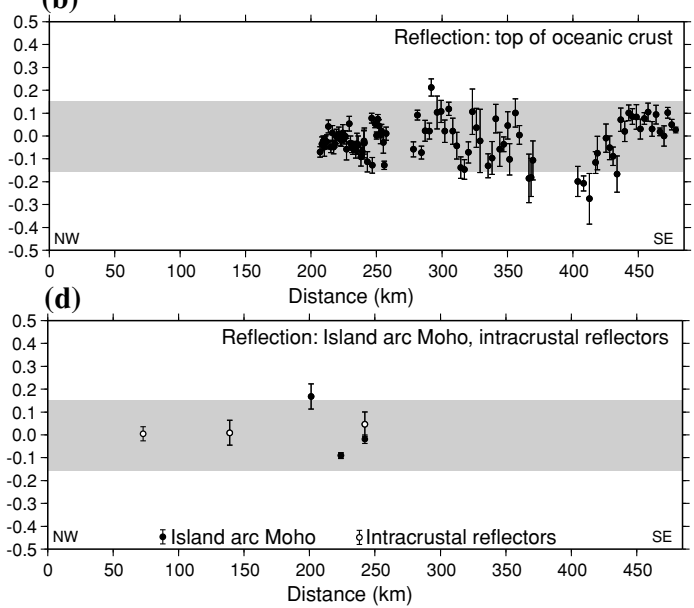

Fig. 7. Travel time residuals of observed phase groups. The mean travel time residual calculated for each station and explosion is plotted at its position. Vertical bars indicate a standard deviation. Horizontal axis is measured from the northern end of the profile. Shaded areas indicate the maximum range of uncertainties of the observed arrival times, $\pm 0.1 \mathrm{~s}$ for refractions and $\pm 0.15 \mathrm{~s}$ for reflections. (a) First arrival refractions, (b) reflections from top of the incoming and subducted crust, (c) reflections from bottom of the incoming and subducted crust, (e) reflections from the Island arc Moho and intra-crustal reflectors.

terpretation of the reflection phases, as several sub-parallel interfaces are observed in the MCS section (Kodaira et al., 2004).

\subsection{Seismic image}

6.2.1 Subducting crust As shown in our previous study (Kodaira et al., 2003), the offshore part of the model is characterized by repeated crustal thickening, which is interpreted as a cyclic ridge subduction consisting of the Paleo-Zenis-north ridge and -south ridge (Fig. 6) (hereafter, referred as to the north ridge and the south ridge, respectively). Kodaira et al. (2003) described the existence of the north ridge, however, could not estimate the landward extension of the ridge due to limitations in the coverage of the data. The newly processed onshore recorded offshore shots enable us to estimate the volume of the subducted ridge system. In Fig. 6, we recognize subducting ridges at $300 \mathrm{~km}$ (the north ridge) and $350 \mathrm{~km}$ (the south ridge) with maximum thicknesses of $12 \mathrm{~km}$ and $20 \mathrm{~km}$, respectively. The north ridge extends beneath the coast line. These thicknesses are estimated more accurately than in the previous study (Kodaira et al., 2003), because this study includes both the top and the bottom of the crust obtained from reflection phases. We emphasize that the volume of the north ridge is larger than that of the present day Zenisu ridge (the width of the north ridge and the present day Zenisu ridge are $60 \mathrm{~km}$ and $40 \mathrm{~km}$, respectively), whereas the south ridge is smaller than both of these ridges.

The subducting crust can be traced down to $45 \mathrm{~km}$ depth beneath the Japanese island. The geometry of the subducting crust was mainly obtained from the wide-angle reflection phases from the land explosions. The clearly observed reflection phase for land explosion J5 (Fig. 4(b)) provides an accurate geometry for the top of the subducting oceanic crust between $180-250 \mathrm{~km}$ at $45-25 \mathrm{~km}$ depth. The subducting crust in this area was already imaged in a previous study (Iidaka et al., 2003), however the dip angle is slightly shallower in this study. We believe our obtained dip angle may be more reliable as we included onshore recorded offshore shots for estimating the velocity above the reflector around the coastline. It is also emphasized that a slight doming structure ( $2 \mathrm{~km}$ high) on top of the subducted crust can be recognized at 190-230 km (Figs. 6(a) and (b)). This may be attributed to an even deeper ridge system that has already been subducted beneath central Japan.

At around $40 \mathrm{~km}$ depth, the top and bottom of the subducted crust are plotted at $155-180 \mathrm{~km}$ and $200-215 \mathrm{~km}$, respectively. As described below, the uncertainties in this region are high, because the onsets of the observed reflection phases used for obtaining these reflectors are obscure.

6.2.2 Overriding crust The structure of the overriding plate is characterized by an accretion related accretionary wedge and two-layered island arc crust. From the Zenisu ridge to near the coast line $(250-370 \mathrm{~km})$, the accretionary wedge above the subducting crust can be divided into two parts based on differences in the velocity gradient; i.e., a higher velocity gradient block with a velocity of $2-5 \mathrm{~km} / \mathrm{s}$ above a lower velocity gradient block with a velocity of $5-6 \mathrm{~km} / \mathrm{s}$. Similar variations in velocity gradient with depth have been obtained for the Nankai trough accretionary wedge in previous wide-angle seismic studies (e.g., Nakanishi et al., 2002a; Kodaira et al., 2002; Takahashi et al., 2002). Recently, Nakanishi et al. (2002b) compiled all available wide-angle seismic results. They interpreted the two layers as the Cretaceous-Tertiary accretionary prism underlying the Neogene-Quaternary accretionary prism. They also proposed that the boundary between the two blocks functions as the back stop of the present day accretionary process. In view of this interpretation, we note that our imaged subducted north ridge has already been subducted beneath the back stop, whereas the south ridge is still under the Neogene-Quaternary accretionary prism.

Beneath the Japanese island the seismic velocity image has a similar structure to that obtained in the previous onshore seismic study (Iidaka et al., 2003). Following the interpretation of Iidaka et al. (2003), the onshore structure 

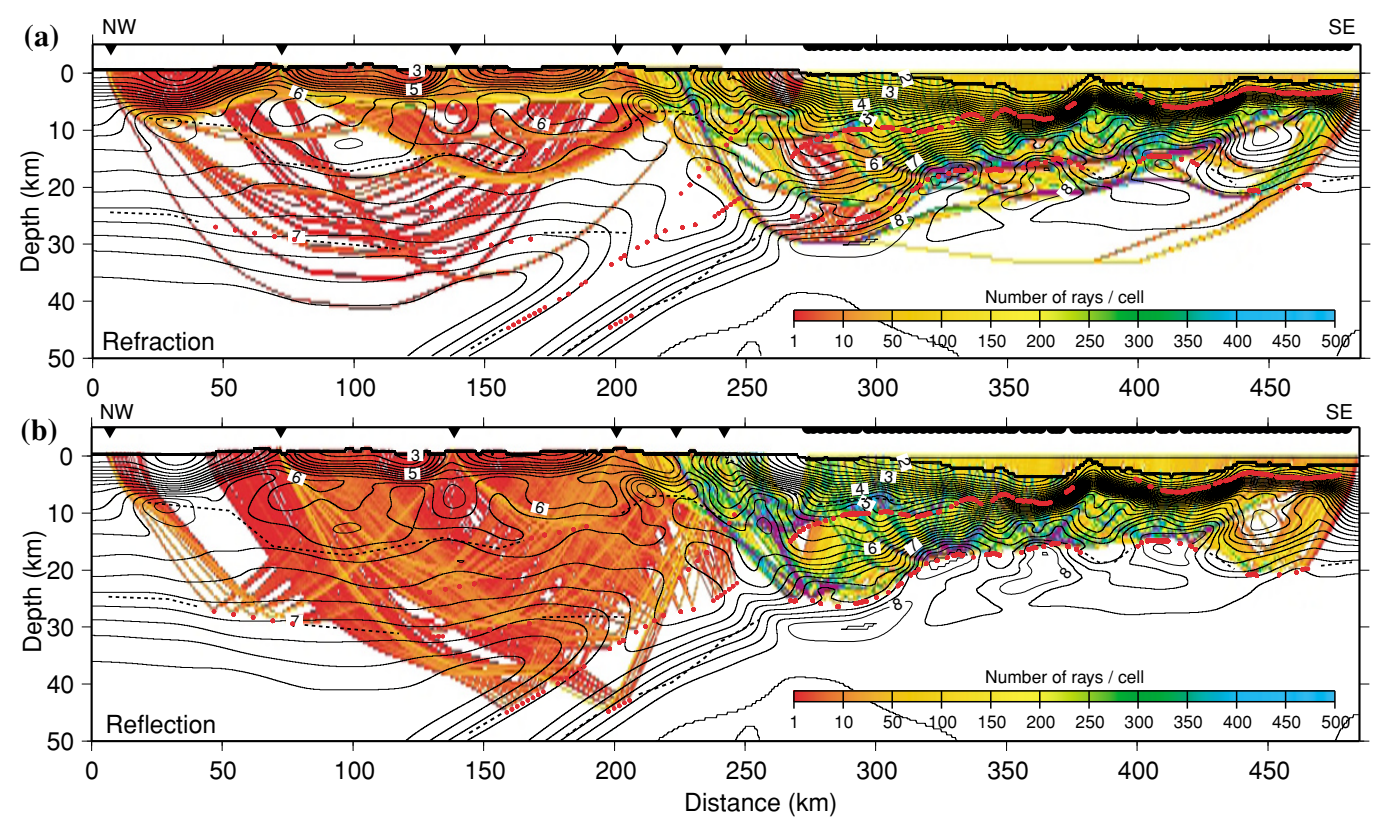

Fig. 8. Number of rays in each cell $(0.5 \times 0.5 \mathrm{~km})$ counting along rays used for modeling. (a) First arrival refractions which control the velocity image. (b) Reflections which determine the geometry of prominent reflectors. Vertical exaggeration is 2.2:1.

is divided into two layers, consisting of a predominantly 6 $\mathrm{km} / \mathrm{s}$ block in the upper half and a $6.4-7.0 \mathrm{~km} / \mathrm{s}$ block in the lower half. Thickening of the $6.0 \mathrm{~km} / \mathrm{s}$ block beneath the central part of the onshore profile $(70-220 \mathrm{~km}$, referred to as the central mountain range) with maximum thickness of $20 \mathrm{~km}$, is more clearly imaged in this study using the tomographic approach. A seismic velocity of $6.0 \mathrm{~km} / \mathrm{s}$ is typical for reported continental upper crust (Christensen and Mooney, 1995). We did not resolve any notable differences in the lower half of the crust.

The seismic velocity structure of the island arc crust is similar to that of northern Japan (Iwasaki et al., 2001), but comparing to structures intra-oceanic island arcs, for example the Izu-Bonin arc (Suyehiro et al., 1996) and Aleutian arc (Holbrook et al., 1999) shows significant differences. A thick high velocity $(\sim 7.3 \mathrm{~km} / \mathrm{s})$ lower crust is obtained in the Izu-Bonin arc, a typical continental upper crust having a $6 \mathrm{~km} / \mathrm{s}$-layer does not imaged in the Aleutian arc. Those differences may reflect a variation of crustal accretionary process in an island arc system.

Several reflectors were obtained in the overriding crust. The most prominent is a steeply landward dipping reflector at 8-20 km depth from $220-250 \mathrm{~km}$, which produced strong wide-angle reflection phases observed at J5 (Fig. 4(b)). This reflector is also clearly imaged in the seismic reflectivity section (Fig. 6(b)), but the dip is slightly different from the reflector obtained from the travel time modeling (Fig. 6(a)). This is because of the strong lateral velocity variation above this interface, i.e., the reflectivity image, obtained with an NMO correction using the average velocity, does not show the true dip. Sato et al. (2002) imaged the same reflector with high resolution reflection data, and interpreted it to be the deeper extension of the Median Tectonic Line, which extends for more than $1000 \mathrm{~km}$ along western Honshu and Kyushu Islands.

Beneath the central mountain range we recognize two intra-crustal reflectors. One is located at the boundary between the $6.0 \mathrm{~km} / \mathrm{s}$ upper crustal block and the $6.4-7.0 \mathrm{~km} / \mathrm{s}$ lower crustal block. The other reflector is located in the middle of the lower crustal body at $20-25 \mathrm{~km}$ depth and is slightly northward dipping. This was obtained from a clear wide-angle reflection phase observed from the land shot $\mathbf{J} 2$ (Fig. 4(a)).

The base of the overriding crust (Island arc Moho) was partly obtained at 50-75 km (27-30 km depth) and 120-170 km (27-30 km depth) from weakly observed wide-angle reflection phases observed at J1 and J5 (e.g. Fig. 4). The Island arc Moho, by interpolating between the two obtained parts of the reflector, shows a deepening toward the central mountain range.

6.2.3 Resolution and reliability of model In this section we describe the results of a checkerboard test to demonstrate the spatial resolution of the seismic velocity structure, and numerical tests to examine the reliability of the key structures of the model.

Checkerboard test: In order to assess model resolution in tomographic studies, checkerboard tests are commonly used (e.g., Hearn and Ni, 1994; Zelt and Barton, 1998). Although details of the test vary, they are generally similar. In this study we followed the checkerboard test described by Zelt and Barton (1998). Synthetic data from a known model consisting of the preferred starting model with an anomaly pattern of positive and negative regions were inverted using the same method as that used to obtain the final model. The lateral anomaly pattern is a $\sin (x) \sin (y)$ function form with a peak anomaly value of $+/-5 \%$ of the background velocity. The observed source-receiver geometry was used and the data were inverted using the same starting model. Looking at the ray coverage, in which the offshore part has a significantly denser ray coverage than the onshore part (Fig. 8), we would expect higher resolution in the offshore part of the model. We thus introduced a different anomaly 

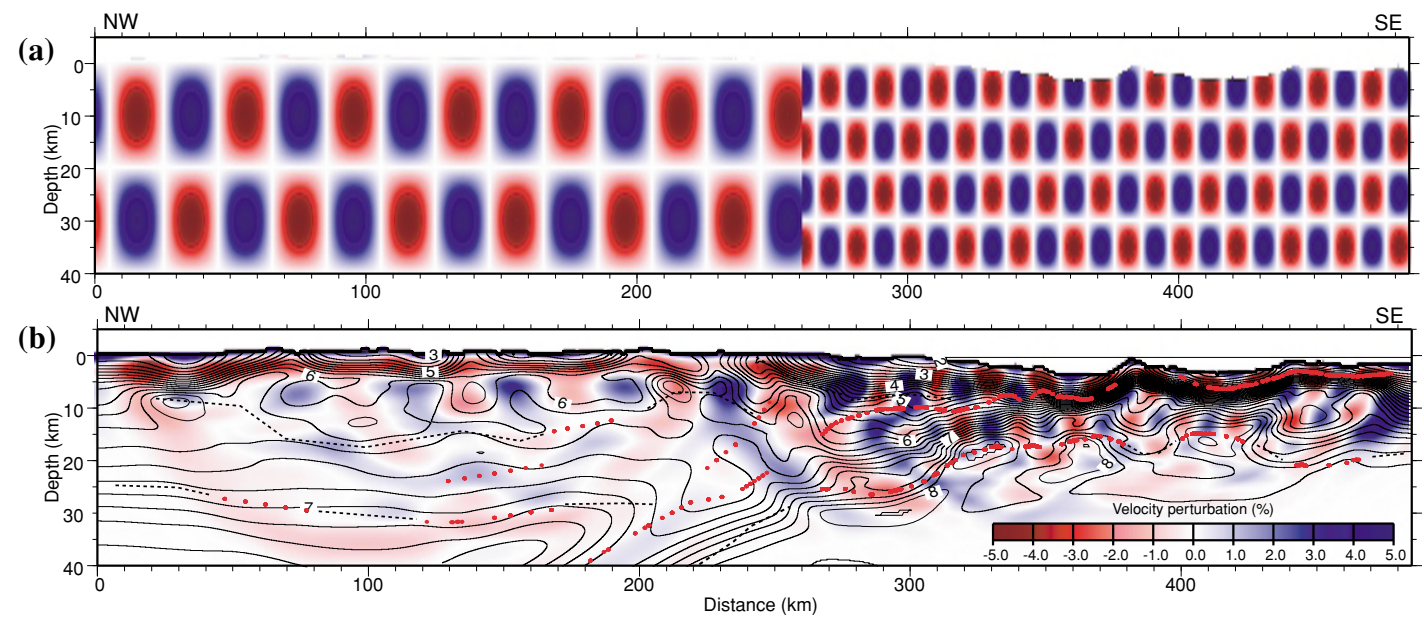

Fig. 9. Checker board test. (a) Initial checkerboard pattern. (b) Final checkerboard pattern. Vertical exaggeration is 2:1.

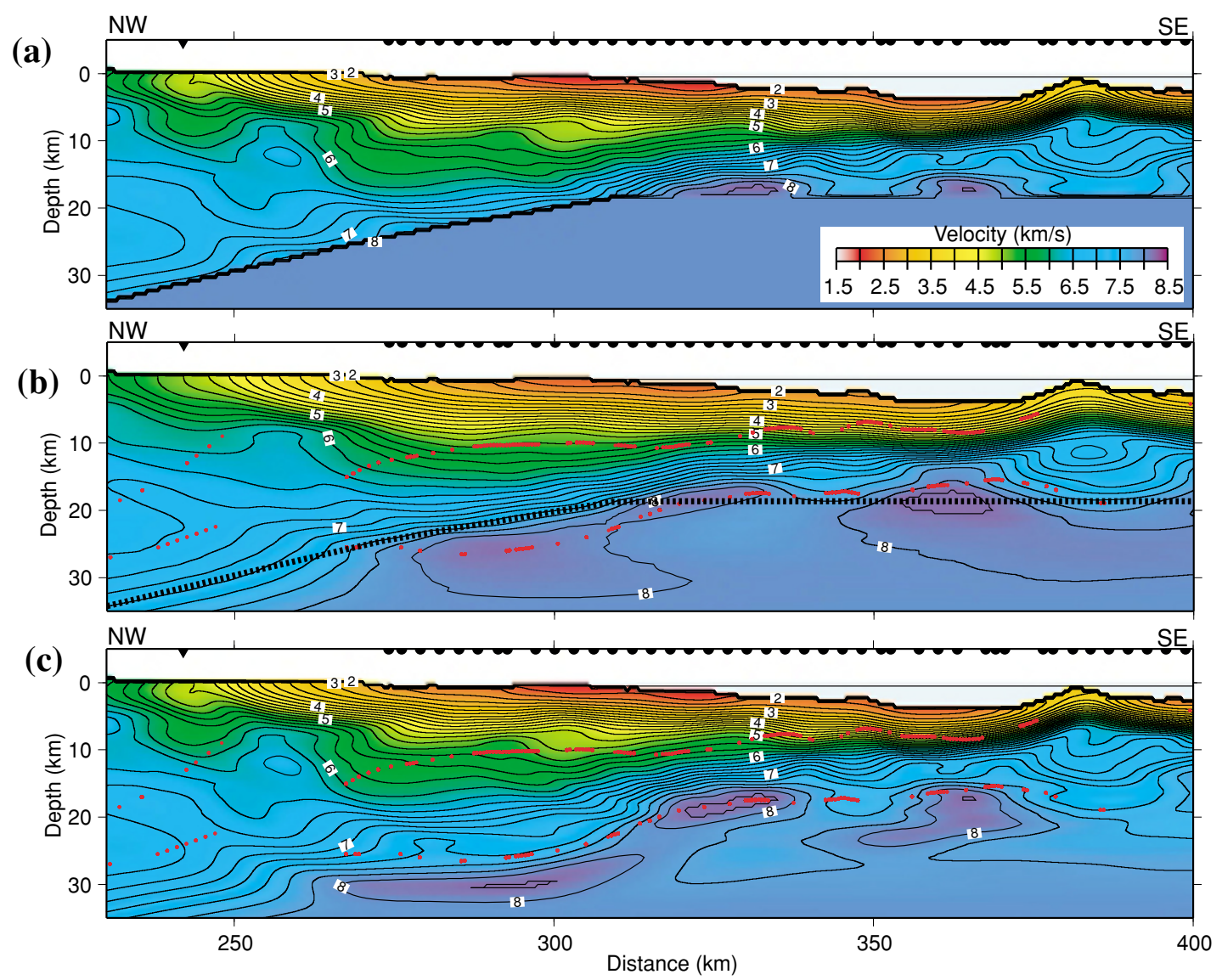

Fig. 10. Numerical test for showing the resolution of the north ridge. (a) Initial model for the test. (b) Final model obtained from the synthetic data. (c) Final model obtained from the observed data. Vertical exaggeration is $1: 1$.

size in the offshore and onshore parts; i.e. $10 \mathrm{~km}$ grids in the offshore part and $20 \mathrm{~km}$ grid in the onshore part.

The result of the checkerboard test shows reasonable recovery of the pattern for the offshore part (Fig. 9). The $10 \mathrm{~km}$ positive-negative patterns are reproduced well in the crust from $275-485 \mathrm{~km}$ (i.e. $0-15 \mathrm{~km}$ depth). This result clearly demonstrates that the repeated $12-20 \mathrm{~km}$ crustal thickening, i.e., the cyclic ridge structure, is well resolved. Around the coastline at $255-275 \mathrm{~km}$, the checker board pattern is elongated along the rays at $10-30 \mathrm{~km}$ depth (cf.,
Fig. 9). As this part corresponds to the landward foot of the north ridge, this is important for estimating the volume of the north ridge. We discuss the reliability of this imaged structure in the next section.

Although, the checker board pattern of the onshore part $(0-255 \mathrm{~km})$ was not as well recovered as that of the offshore part, the checker board pattern corresponding to the $6 \mathrm{~km} / \mathrm{s}$ upper crustal body (5-10 km depth between 25 and $255 \mathrm{~km}$ ) was better recovered than we had expected. This pattern strongly supports our results concerning the $6 \mathrm{~km} / \mathrm{s}$ body, 
(a)
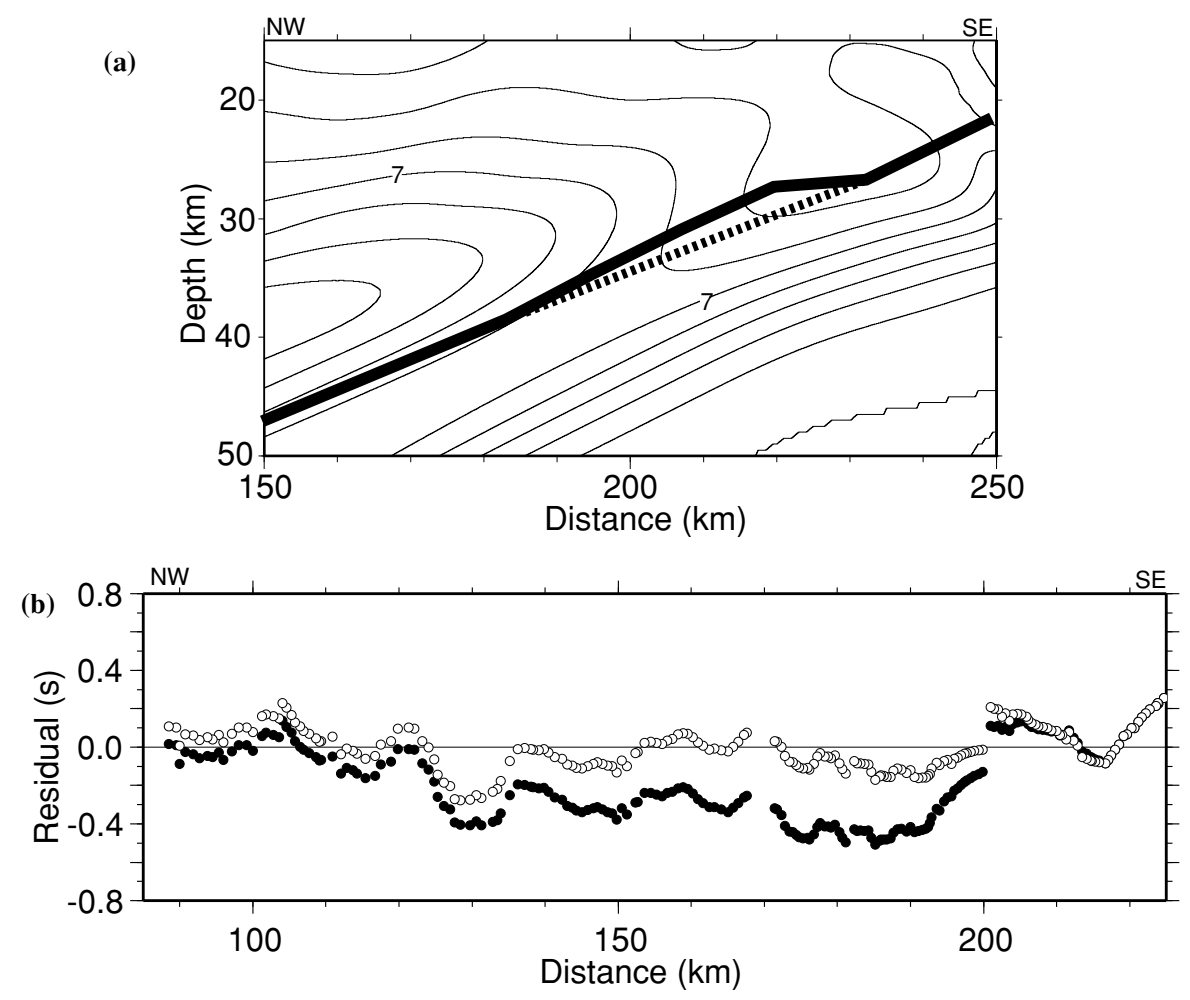

Fig. 11. Numerical test for showing the reliability of the $2 \mathrm{~km}$ high doming structure at the top of subducted crust. (a) Final model (solid line) and tested model (dotted line). Vertical exaggeration is 1.6:1. (b) travel time residuals from the final model (open circles) and the tested model (closed circles).

which thickens toward the central mountain range at least from J5 to J4. In the lower half of the crust the checkerboard pattern shows a broader positive-negative pattern. This indicates that the spatial resolution of this part is larger than 20 $\mathrm{km}$, and the image we obtained may be a smoothed version of the true structure. The most distorted part of the model is in the upper $5 \mathrm{~km}$. The checkerboard test shows horizontally layered positive-negative patterns at depths shallower than $5 \mathrm{~km}$. We can deduce from this that the obtained seismic velocities in the uppermost part $(<2.5 \mathrm{~km}$ deep $)$ maybe overestimated, whereas the velocities at $2.5-5 \mathrm{~km}$ depth may be underestimated to compensate for this overestimation. A reason for the layered distortion would be the sparse shot intervals and, consequently, the horizontally biased ray paths at this depth.

Tests to examine the reliability of key structures: As mentioned above, the cyclic ridge subduction is the most remarkable structure imaged in our model. However, it could be considered from the checkerboard test that the velocity structure imaged at $255-275 \mathrm{~km}$, corresponding to the landward half of the north ridge, may be elongated along the ray paths, and consequently, the volume of the north ridge may have been overestimated. In order to examine if the structure of the north ridge (i.e., the crustal thickening at $255-320 \mathrm{~km}$ ) is an artificial structure due to a biased ray distribution, we performed a simple numerical test as follows. First, we calculated the synthetic travel time data from a test structure (Fig. 10), which included a smoothly dipping Moho in the area where we imaged the north ridge (255-320 km), using the same receiver-shot geometry as the actual data. Second, the inversion of the synthetic data was performed from the same starting model we used for the observed data. We then checked if any artificial crustal thickening appeared.

The inversion (Fig. 10(b)) clearly recovered the smoothly dipping structure at 255-320, whereas an artificial downward distortion of the iso-velocity contours appeared north of $255 \mathrm{~km}$. We conclude from this test that the crustal thickening we obtained for the north ridge was not artificially imaged from a smoothly dipping Moho, but that the imaged structure showing downward steps of the iso-velocity contours north of $255 \mathrm{~km}$ is more likely to be an artificial structure caused by biased ray coverage.

As discussed above, there is a possibility of an even deeper ridge structure consisting of the $2 \mathrm{~km}$ high doming structure at the top of the subducted crust at 190-230 $\mathrm{km}$. In order to test the reliability of this structure, we compared the travel times calculated from the final model with those calculated from a smoothly landward dipping interface (Fig. 11). Reflection travel times are affected by both the geometry of the interface and the velocity above it (Fig. 6). We therefore, assumed the seismic velocity above the interface as shown in Fig. 6 during the test, and then examined the effects of an undulation of the interface on the travel time data.

We compared the reflection travel times calculated from an interface with a $2 \mathrm{~km}$ high doming structure (final model) and a smoothly dipping interface (Fig. 11(a)). As shown in Fig. 11(b), the reflection travel times calculated from the smoothly dipping reflectors are $0.4 \mathrm{~s}$ slower than the observed travel times between 135 and $190 \mathrm{~km}$, whereas the travel times calculated form the final model fit within $0.1 \mathrm{~s}$. 
From this we conclude that the $2 \mathrm{~km}$ high doming structure at the top of the subducted oceanic crust at $30 \mathrm{~km}$ depth, presumably indicating an even deeper ridge, is a resolvable structure when the seismic velocity is assumed as is shown in Fig. 6. A small scale velocity perturbation which cannot be resolved may affect on a small scale perturbation of the shape of the doming structure.

\subsection{Effect of ridge subduction on co-seismic/inter- seismic slips}

The most significant structure from the eastern Nankai Trough to central Japan is the cyclic ridge subduction. The possibility of a subducted ridge in this area had been previously suggested at the depth of our obtained south ridge based on several geophysical and geological studies. Recent improvements in the quality of seismic reflection data have greatly helped to image the subducted ridge at depths shallower than $10 \mathrm{~km}$. For example, Park et al. (2003) mapped a subducted ridge that continues from offshore Kii peninsula to offshore of the Tokai district using compiled multichannel seismic data. Our imaged south ridge is the eastern most member of this ridge. Dessa et al. (2004) also imaged a subducted ridge immediately west of the south ridge using high resolution OBS data. Park et al. (2003) concluded from mapping that the western half of the ridge, which is located off the Kumano basin, is colliding with the back stop. In other words, the eastern half of the ridge has not yet reached the back stop.

A few previous studies imaged a ridge structure at the depth of the north ridge. Kodaira et al. (2003) first showed structural evidence for a north ridge, even though only the seaward half of the ridge was imaged due to the limitation of the profile length. Nakanishi et al. (2002a) obtained an abrupt deepening of the subducted Moho $50 \mathrm{~km}$ east of the north ridge. This structure was obtained at the end of their profiles, resulting in poor resolution, however, because of the similarity between their structure and our image of the north ridge, we consider that the abrupt deepening of the Moho may represent crustal thickening due to a westward continuation of the north ridge.

On the basis of GPS data, Sagiya (1999) obtained a back slip rate of more than $35 \mathrm{~mm} /$ year $50 \mathrm{~km}$ offshore of the Tokai district, which is comparable to the plate convergent rate. Comparing the location and size of the north ridge and the back slip rate, Kodaira et al. $(2003,2004)$ showed that the north ridge is situated in the area where strong coupling is expected from the large back slip rate. As described in the introduction, the slip distribution of the 1944 Tonankai earthquake obtained from tsunami and earthquake data indicated that the co-seismic slip was concentrated in the $\mathrm{Ku}$ mano basin (Segment C in Fig. 1), but did not extend to the Tokai segment (Fig. 1). Historical earthquake data also suggest that the recurrence intervals for offshore Tokai are not as regular as those for the other segments (e.g. Ando, 1975). This slip distribution and longer recurrence interval may be explained well by a stronger coupling due to ridge subduction under the back stop. Kodaira et al. $(2003,2004)$ thus proposed that the subducted ridge under the back stop may have prevented eastward propagation of the co-seismic slip during the 1944 Tonankai earthquake.

Recently Kanda et al. (2003) used ground motion in- tensity data, including historical earthquake in the Nankai trough, to show that an area of strong energy release in some historical earthquakes can be recognized where the ridge/seamount is being subducted. This is interpreted to mean that the proposed strong coupled area due to ridge/seamount subduction may be sometimes ruptured when the accumulating stress exceeds the critical strength of the coupled area.

From a global point of view of ridges/seamounts subduction, it should be mentioned that ridge/seamounts on incoming plate may not be always subducted. A recent structural study in the Ontong Java plateau (Miura et al., 2004) clearly shows accretion of a upper half of its thick crustal body (30 km thick). This is good evidence indicating that ridge/seamount subduction may depend on their size and volume.

Another remarkable structure imaged in this study is the highly reflective oceanic crust that is subducting under central Japan down to $45 \mathrm{~km}$ depth. Moreover, the velocity and reflectivity images indicate a $2 \mathrm{~km}$ high doming structure at the top of the oceanic crust at $30-40 \mathrm{~km}$ depth. Several seismic studies have imaged similar highly reflective layers at several depth ranges in subduction zones. For example, in the central Cascadia margin off Oregon, Gerdom et al. (2001) obtained a strong reflection phase from the top of the subducting crust at $18-25 \mathrm{~km}$ depth. In the western Nankai Trough, Kodaira et al. (2002) imaged highly reflective oceanic crust at a similar depth (15-27 km depth). In the northern Cascadia margin, at Vancouver island, Hyndman (1988) discussed a strong reflector at 20-30 km depth that is situated slightly above the oceanic crust. The ANCORP Working Group (2003) imaged a bright reflector at $30-75 \mathrm{~km}$ depth that is most likely linked to the subducting oceanic plate in the central Andes. All these strong reflectors were considered to be related to fluid interpreted to form by dehydration of subducting oceanic plates, as all studies except Gerdom et al. (2001) found evidence of low velocity or high $V p / V s$ (and consequently high Poisson's ratio) structures.

Recently, seismic tomography for central Japan (Kamiya and Kobayashi, 1997, 2000), imaged a landward dipping high Poisson's ratio zone $(\sim 0.34)$. This structure occurs only in the Tokai district, at $25-55 \mathrm{~km}$ depth. The high reflectivity zone is situated in the same place as the high Poisson's ratio zone (Kodaira et al., 2004) (Fig. 12). Kodaira et al. (2004) proposed a high pore pressure zone as a possible cause of the highly reflective zone, and discussed a mechanism for the transportation of water into the subducted oceanic crust. A possible mechanism for generating a high pore fluid pressure zone in subducting oceanic crust is a dehydration of hydrous minerals in the oceanic crust (Hacker et al., 2003; Kodaira et al., 2004). We also propose that the zone of high pore fluid pressure reaches around subduction interface, because the highly reflective nature at the subduction interface indicates a large acoustic impedance contrast. A part of the high pore fluid pressure may leak into the overriding plate immediately above the plate interface, like a proposed model in the Cascadia margin (Nedimovic et al., 2003; Brocher et al., 2003; Preston et al., 2003). This may by supported by the partly observed reverberation of 


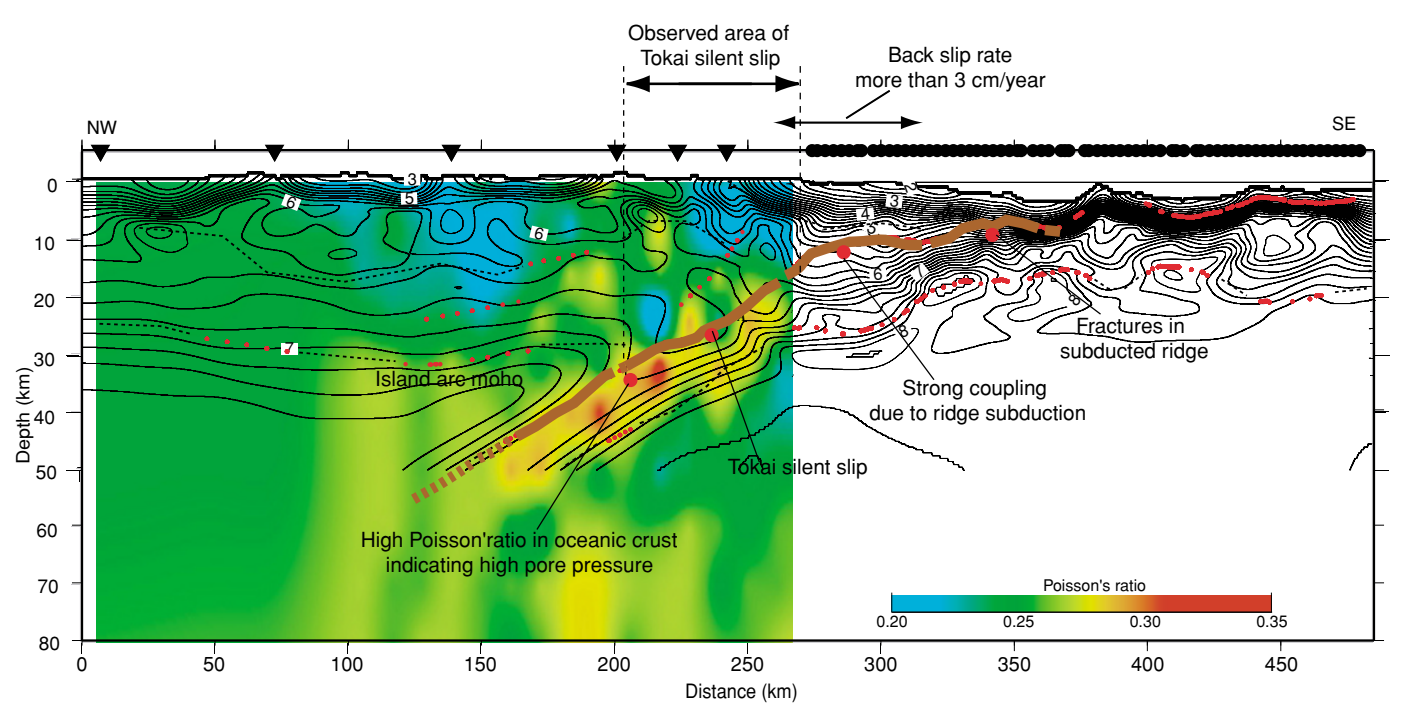

Fig. 12. Poisson's ratio structure obtained by Kamiya and Kobayashi (1997, 2000) superimposed on the seismic velocity structure from Fig. 6(a) (the original figure from Kodaira et al., 2004). An area indicating back slip rate of more than $3 \mathrm{~cm} /$ year (Sagiya, 1999) is shown at the top of the figure. Vertical exaggeration is $2.2: 1$.

the reflection phase from the plate interface (e.g., $30-50 \mathrm{~km}$ offset in Fig. 4(b)).

Kodaira et al. (2004) also concluded that the highly reflective/high Poisson's ratio zone effectively extends the conditionally stable slip zone, which can generate silent slip in the subduction zone (e.g., Scholz, 1998) at the Tokai segment. This is because pore fluid pressure may approach normal stress in a high pore pressure zone (i.e. effective normal stress may approach to zero), and the critical stiffness of the plate interface would decrease as a result, maintaining a conditionally stable region over the high pore pressure zone.

\section{Conclusions}

The onshore-offshore crustal transect from the western edge of the Izu island arc to central Japan is characterized by a series of subducting ridges. The seismic velocity and reflectivity images clearly show two subducted ridges with a $50 \mathrm{~km}$ separation offshore of the Tokai district: the south ridge and the north ridge. The two subducted ridges are $12 \mathrm{~km}$ thick by $40 \mathrm{~km}$ wide, and $20 \mathrm{~km}$ thick by $60 \mathrm{~km}$ wide, respectively. This indicates that the crustal volume of the north ridge, currently subducted to a depth of $10 \mathrm{~km}$, is larger than that of the Zenisu ridge. From the travel times of wide-angle reflection phases, the top of the subducting oceanic crust can be traced down to $45 \mathrm{~km}$ depth beneath central Japan, and shows evidence for a $2 \mathrm{~km}$ high doming structure at $30-40 \mathrm{~km}$ depth. This may indicate an even deeper ridge system subducted under central Japan.

From the coast line to the Nankai Trough, a wedge shaped low velocity layer $(2.0-5.0 \mathrm{~km} / \mathrm{s})$ is imaged above the subducting crust. This is interpreted as young (presumably Neogene-Quaternary) accretionary material. The lower boundary of this layer is proposed to form a back stop to the present day accretion system. The north ridge lies beneath the back stop whereas the south ridge has not yet reached at the back stop. The central Japan crust is described as a simple two layered crustal structure with a 6.0 $\mathrm{km} / \mathrm{s}$ layer and $6.4-7.0 \mathrm{~km} / \mathrm{s}$ layer. The total thickness of the two layers is about $30 \mathrm{~km}$. The subducting oceanic crust is imaged as a highly reflective layer at $25-45 \mathrm{~km}$ depth beneath central Japan. The $2 \mathrm{~km}$ high doming structure is resolved at this highly reflective region of the subducting crust. This structure may indicate an even deeper subducted ridge.

Comparing the structure of the ridge subduction and the back slip distribution obtained from GPS data indicates that the north ridge is situated precisely where the largest back slip rate of $\sim 4 \mathrm{~cm}$ is estimated. This indicates that there is a strong coupling between the plates off the Tokai district due to ridge subduction under the back stop. As the slip distribution of the 1944 Tonankai earthquake did not extend to the offshore Tokai district, we propose that the subducted ridge under the back stop may have prevented eastward slip propagation because of the strong coupling at the subducting ridge in this region. The highly reflective subducting oceanic crust at $25-45 \mathrm{~km}$ depth beneath central Japan is located in the same place as the high Poisson's ratio $(\sim 0.34)$ zone, which is localized only in the Tokai district. We propose that the highly reflective/high Poisson's ratio zone can be attributed to water in the subducted crust, and that this significantly extends the conditionally stable region, which generates the silent slip observed in the Tokai segment.

Acknowledgments. Part of this study is a contribution of the research program at the Institute for Research on Earth Evolution (IFREE), JAMSTEC. We thank Captain Ishida, his crew, and the technical staff on board the R/V Kaiyo for their efforts during the offshore seismic data acquisition. We also thank scientists, technicians and students from University of Tokyo, Kyoto University, Hokkaido University, Nagoya University, Japan Meteorological Agency and members of the Research Group for Seismic Expedition in Central Japan for their support in maintaining the land stations. We finally acknowledge Dr. K. Suyehiro, Dr. T. Yuku- 
take, Dr. A. Kato, Dr. S. Kamiya, Prof. G. Kimura and Prof. M. Toriumi for discussions and encouragements during this study.

\section{References}

ANCORP Working Group, Seismic imaging of a convergent continental margin and plateau in the central Andes (Andean Continental Research Project 1996 (ANCORP'96)), J. Geophys. Res., 108, 2328, doi:10.1029/ 2002JB001771, 2003.

Ando, M., Source mechanisms and tectonic significance of historical earthquakes along the Nankai Trough, Tectonophysics, 27, 119-140, 1975.

Aoki, Y., T. Tomono, and S. Kato, Detailed structure of the Nankai trough from migrated seismic sections, in Continental Margin Geology, edited by J. S. Watkins and C. L. Drake, Am. Assoc. Pet. Geol. Mem., 34, 309-322, 1982.

Baba, T., Y. Tanioka, P. R. Cummins, and K. Uhira, The slip distribution of the 1946 Nankaido earthquake estimated from tsunami inversion using a new plate model, Phys. Earth Planet. Interior., 132, 59-74, 2002.

Baba, T., P. R. Cummins, T. Hori, and Y. Kaneda, The influence of plate boundary topography on interpolate earthquakes: Slip distributions of the 1944 Tonankai and 1946 Nankai earthquakes deduced from tsunami waveforms, Tectonophysics, in press.

Brocher, T. M., T. Parsons, A. M. Trehu, C. M. Snelson, and M. A. Fishre, Seismic evidence for widespread serpentinized forearc upper mantle along the Cascadia margin, Geology, 31(3), 267-270, 2003.

Christensen, N. I. and W. D. Mooney, Seismic velocity structure and composition of the continental crust: A global view, J. Geophys. Res., 100, 9761-9788, 1995.

Cummins, P. R., T. Baba, S. Kodaira, and Y. Kaneda, The 1946 Nankai earthquake and segmentation of the Nankai Trough, Phys. Earth Planet. Interior, 132, 75-87, 2002.

Dessa, J.-X., S. Operto, S. Kodaira, A. Nakanishi, G. Pascal, K. Uhira, and Y. Kaneda, Deep seismic imaging of the eastern Nankai trough, Japan, from multifold OBS data by combined traveltime tomography and prestack depth migration, J. Geophys. Res., 109, 10.1029/ 2003JB002689, 2004.

Gerdom, M., A. M. Trehu, E. R. Flueh, and D. Klaeschen, The continental margin off Oregon from seismic investigations, Tectonophysics, 329, 79-97, 2001.

Hacker, B. R., G. A. Abers, and S. M. Peacock, Subduction factory 1. Theoretical mineralogy, densities, seismic wave speeds, and $\mathrm{H}_{2} \mathrm{O}$ contents, J. Geophys. Res., 108, 2029, doi:1029/2001JB001127, 2003.

Hearn, T. M. and J. F. Ni, Pn velocities beneath continental collision zones: The Turkishi-Iranian Plate, Geophys. J. Int., 117, 273-283, 1994.

Heki, K. and S. Miyazaki, Plate convergence and long-term crustal deformation in central Japan, Geophys. Res. Lett., 28, 2313-2316, 2001.

Holbrook, S. W., D. Lizarralde, S. McGeary, N. Bangs, and J. Diebold, Structure and composition of the Aleutian island arc and implications for continental crustal growth, Geology, 27, 31-34, 1999.

Hole, J. A. and B. C. Zelt, 3-D finite-difference reflection travel times, Geophys. J. Int., 121, 427-434, 1995.

Hyndman, R. D., Dipping seismic reflectors, electrically conductive zones, and trapping water in the crust over a subducting plate, J. Geophys. Res., 93, 13391-13405, 1988

Iidaka, T., T. Iwasaki, T. Takeda, T. Moriya, I. Kumuakawa, E. Kurashimo, T. Kawamura, F. Yamazaki, K. Koike, and G. Aoki, Configuration of subducting Philippine Sea plate and crustal structure in the central Japan region, Geophys. Res. Lett., 30, 1219, doi:10.1029/2002/GL016517, 2003.

Ishibashi, K., Reconsideration of an expected great earthquake in the Tokai district; a possibility of the bay of Suruga earthquake, Japan seismological society abstract, 2, 30-34, 1976.

Ishizuka, O., K. Uto, M. Yuasa, and A. G. Hochstaedter, K-Ar ages from seamount chains in the back-arc region of the Izu-Ogasawara arc, The Island Arc, 7, 408-421, 1998.

Iwasaki, T., W. Kato, T. Moriya, A. Hasemi, N. Umino, T. Okada, K. Miyashita, T. Mizogami, T. Takeda, S. Sekine, T. Matsushima, K. Tashiro, and H. Miyamachi, Extensional structure in northern Honshu Arc as inferred from seismic refraction/wide-angle reflection profiling, Geophys. Res. Lett., 28, 2329-2332, 2001.

Kamiya, S. and Y. Kobayashi, Detection of serpentinized wedge mantle beneath the Tokai district, Japan, abst 1997 Japan Earth and planetary science joint meeting, C21-04, 1997

Kamiya, S. and Y. Kobayashi, Seismological evidence for the existence of serpentinized wedge mantle, Geophys. Res. Lett., 27, 819-822, 2000.

Kanazawa, T. and H. Shiobara, Newly developed ocean bottom seismome- ter, Prog. Abst. Japan Earth and Planetary Science Joint Meeting, 2, 240 , 1994.

Kanda, K., M. Takemura, and T. Usami, Inversion analysis of distribution of energey radiated from an earthquake fault based on the seimic intensity data, Zishin, 56, 39-58, 2003.

Kikuchi, M., M. Yamanaka, and K. Yoshikawa, Source rupture process of the 1944 Tonankai earthquake and the 1945 Mikawa earthquake derived from low-gain seismograms, Earth Planets Space, 55, 159-172, 2003.

Kinoshita, H. and N. Matsuda, Seismic structure and geomagnetic anomaly in the Nankai Trough related to subduction of the Philippine Sea plate, J. Geomag. Geoelectr., 41, 161-173, 1989.

Kobayashi, K., S. Kasuga, and K. Okino, Shikoku Basin and its Margins, in Backarc Basins: Tectonics and Magmatism, pp. 381-405, edited by B. Taylor, Plenum Press, New York, 1995.

Kodaira, S., N. Takahashi, J.-O. Park, K. Mochizuki, M. Shinohara, and S. Kimura, Western Nankai Trough seismogenic zone: Results from a wide-angle ocean bottom seismic survey, J. Geophys. Res., 105, 58875905, 2000a.

Kodaira, S., N. Takahashi, A. Nakanishi, S. Miura, and Y. Kaneda, Subducted seamount imaged in the rupture zone of the 1946 Nankaido earthquake, Science, 289, 104-106, 2000b.

Kodaira, S., E. Kurahimo, J.-O. Park, N. Takahashi, A. Nakanishi, S. Miura, T. Iwasaki, N. Hirata, K. Ito, and Y. Kaneda, Structural factors controlling the rupture process of a megathrust earthquake at the Nankai trough seismogenic zone, Geophys. J. Int., 149, 815-835, 2002.

Kodaira, S., A. Nakanishi, J.-O. Park, A. Ito, T. Tsuru, and Y. Kaneda, Cyclic ridge subduction at an inter-plate locked zone off central Japan, Geophys. Res. Lett., 30, 1339, doi:10.1029/2002GL016595, 2003.

Kodaira, S., T. Iidaka, A. Kato, J.-O. Park, T. Iwasaki, and Y. Kaneda, High pore fluid pressure may cause silent slip in the Nankai Trough, Science, 304, 1295-1298, 2004.

Lallemand, S. E., J. Malavieille, and S. Calassou, Effects of oceanic ridge subduction on accretionary wedges: Experimental modeling and marine observations, Tectonics, 11, 1301-1321, 1992.

Le Pichon, X., S. Lallemant, H. Tokuyama, E. Thoue, P. Huchon, and P. Henry, Structure and evolution of the backstop in the eastern Nankai trough area (Japan): Implications for the soon-to-come Tokai earthquake, The Island Arc, 5, 440-454, 1996.

Mazzotti, S., X. Le Pichon, P. Henry, and S. Miyazaki, Full interseismic locking of the Nankai and Japan-west Kurile subduction zones; an analysis of uniform elastic strain accumulation in Japan constrained by permanent GPS, J. Geophys. Res., 105, 13159-13177, 2000.

Mazzotti, S., S. Lallemant, P. Henry, X. Le Pichon, H. Tokuyama, and N. Takahashi, Intraplate shortening and underthrusting of a large basement ridge in the eastern Nankai subduction zone, Marine Geol., 187, 63-88, 2002

Miura, S., K. Suyehiro, M. Shinohara, N. Takahashi, E. Araki, and A. Taira, Seismological structure and implications of collision between the Ontong Java Plateau and Solomon Island Arc from ocean bottom seismometer-airgun data, Techtonophysics, 389, 191-220, 2004.

Moore, G. F., T. H. Shipley, P. L. Stoffa, D. E. Karig, A. Taira, S. Kuramoto, H. Tokuyama, and K. Suyehiro, Structure of the Nankai Trough accretionary zone from multichannel seismic reflection data, J. Geophys. Res., 95, 8753-8765, 1990.

Moser, T. J., Shortest path calculation of seismic rays, Geophysics, 56, 5967, 1991.

Nakamura, K., S. Uchida, and K. Shibata, Chemistry and K-Ar age of igneous rocks dredged at the Zenisu Ridge, Bull. Volcanological Soc. Japan, 32, 181, 1987.

Nakanishi, A., H. Shiobara, R. Hino, S. Kodaira, T. Kanazawa, and H. Shimamura, Detailed subduction structure across the eastern Nankai Trough obtained from OBS profiles, J. Geophys. Res., 103, 2715127168, 1998.

Nakanishi, A., H. Shiobara, R. Hino, K. Mochizuki, T. Sato, J. Kasahara, N. Takahashi, K. Suyehiro, H. Tokuyama, J. Segawa, M. Shinohara, and H. Shimamura, Deep crustal structure of the eastern Nankai Trough and Zenisu Ridge by dense airgun-OBS seismic profiling, Marine Geol., 187, 47-62, 2002a.

Nakanishi, A., N. Takahashi, J.-O. Park, S. Miura, S. Kodaira, Y. Kaneda, N. Hirata, T. Iwasaki, and M. Nakamura, Crustal structure across the coseismic rupture zone of the 1944 Tonankai earthquake, the central Nankai Trough seismogenic zone, J. Geophys. Res., 107, EPM2-1-2-21, 2002b.

Nakanishi, A., S. Kodaira, J.-O. Park, and Y. Kaneda, Deformable backstop as seaward end of coseismic slip in the Nankai Trough seismogenic 
zone, Earth Planet. Sci. Lett., 203, 255-263, 2003.

Nedimovic, M. R., R. D. Hyndman, K. Ramachandra, and G. D. Spence, Reflection signature of seismic and aseismic slip on the northern Cascadia subduction thrust, Nature, 424, 416-420, 2003.

Nishisaka, H., M. Mochida, M. Shinohara, R. Hino, J. Kasahara, T. Sato, K. Mochizuki, H. Katao, K. Suyehiro, T. Kanazawa, T. Maeda, T. Iwasaki, N. Hirata, and T. Yoshii, Crustal structure of Nankai Trough, off Siono Cape and Kii-Suidou using ocean bottom seismometer and controlled sources, paper presented at Japan Earth and Planetary Science Joint Meeting, Seismol. Soc. Jpn., Tokyo, 1997.

Nishizawa, A. and K. Suyehiro, Crustal structure of the Nankai Trough obtained by OBS data, Chikyu, 111, 645-650, 1989.

Okino, K., Y. Ohara, S. Kasuga, and Y. Kato, The Philippine Sea: New survey results reveal the structure and the history of the marginal basins, Geophys. Res. Lett., 26, 2287-2290, 1999.

Ozawa, S., M. Murakami, M. Kaidzu, T. Tada, T. Sagiya, Y. Hatanaka, H. Yari, and T. Nishimura, Detection and monitoring of ongoing aseismic slip in the Tokai region, central Japan, Science, 298, 1009-1012, 2002.

Park, J.-O., T. Tsuru, S. Kodaira, P. R. Cummins, and Y. Kaneda, Splay fault branching along the Nankai subduction zone, Science, 297, 11571160, 2002.

Park, J.-O., G. F. Moore, T. Tsuru, S. Kodaira, and Y. Kaneda, A subducted oceanic ridge influencing the Nankai megathrust earthquake rupture, Earth Planet. Sci. Lett., 217, 77-84, 2003.

Preston, L. A., K. C. Creager, R. S. Crosson, T. M. Brocher, and A. M. Trehu, Intraslab earthquakes: Dehydration of the Cascadia slab, Science, 302, 1197-1200, 2003.

Sakamoto, I. and Y. Kim, Petrographical characteristics of volcanic rocks sampled from Kosyu seamount, northern part of Shikoku basin, Bull. department of marine science, Tokai Univ., 48, 145-159, 1999.

Sangawa, A., History of the earthquake obtained from ruins and soil liquefaction, Kagaku, 68, 20-24, 1998.

Sagiya, T., Interplate coupling in the Tokai district, central Japan, deduced from continuous GPS data, Geophys. Res. Lett., 26, 2315-2318, 1999.

Sato, H. et al., Seismic reflection image of lithospheric structure beneath Shitara, Tokai, central Japan. abst. Japan Earth and Planetary science Joint Meeting, S052-016, 2002.

Scholz, C. H., Earthquakes and friction laws, Nature, 391, 37-42, 1998.

Seno, T., S. Stein, and A. E. Gripp, A model for the motion of the Philippine Sea plate consistent with NUVEL-1 and geological data, J. Geophys. Res., 98, 17941-17948, 1993.

Shinohara, M., K. Suyehiro, S. Matsuda, and K. Ozawa, Digital recording ocean bottom seismometer using portable digital audio tape recorder, Journal of the Japan Society for Marine Surveys and Technology, 5, 21-31, 1993.

Shiono, S. and N. Sugi, Life of an oceanic plate: Cooling time and assimi- lation time, Tectonophysics, 112, 35-50, 1985.

Sugi, N. and S. Uyeda, Subduction of young oceanic plates without deep focus earthquakes, Bull. Soc. Geol. France, 26, 245-254, 1984.

Sugiyama, Y., Neotectonics of Southwest Japan due to the right-oblique subduction of the Philippine Sea Plate, Geofisica Inernacional, 33, 53$76,1996$.

Suyehiro, K., N. Takahashi, Y. Ariie, Y. Yokoi, R. Hino, M. Shinohara, T. Kanazawa, N. Hirata, H. Tokuyama, and A. Taira, Continental crust, crustal underplating and low-Q upper mantle beneath an oceanic island arc, Science, 272, 390-392, 1996.

Taira, A. et al., Proceedings of Ocean Drilling Program, Initial Reports, 131, Ocean Drilling Program, College Station, Texas, 1991.

Takahashi, N., H. Amano, K. Hirata, H. Kinoshita, S. Lallemant, H. Tokuyama, F. Yamonomo, A. Taira, and K. Suyehiro, Faults configuration around the eastern Nankai trough deduced by multichannel seismic profiling, Marine Geol., 187, 31-46, 2002.

Tanioka, Y. and K. Satake, Detailed coseismic slip distribution of the 1944 Tonankai earthquake estimated from tsunami wave forms, Geophys. Res. Lett., 28, 1075-1078, 2001a.

Tanioka, Y. and K. Satake, Coseismic slip distribution of the 1946 Nankai earthquake and aseismic slips caused by the earthquake, Earth Planets Space, 53, 235-241, 2001b.

Wells, R. R., R. J. Blakely, Y. Sugiyama, D. W. Scholl, and P. A. Dinterman, Basin-centerd asperities in great subduction zone earthquakes; a link between slip, subsidence and subduction erosion, J. Geophys. Res., 108(B10), 2507, doi:10.1029/2002JB002072, ESE 16-1 to 16-30, 2003.

Yuasa, M., Sofugan tectonic line, a new tectonic boundary separating northern and southern parts of the Izu-Ogasawara (Bonin) arc, nothwest Pacific, in Formation of Active Ocean Margins, edited by N. Nasu, K. Kobayashi, S. Uyeda, I. Kushiro, and H. Kagami, pp. 483-486, Terra Scientific Publishing Company, Tokyo, 1985.

Zelt, C. A. and P. J. Barton, 3D seismic refraction tomography: A comparison of two methods applied to data from the Faeroe Basin, J. Geophys. Res., 103, 7187-7210, 1998.

Zelt, C. A., K. Sain, J. V. Naumenko, and D. S. Sawyer, Assessment of crustal velocity models using seismic refraction and reflection tomography, Geophys. J. Int., 153, 595-608, 2003.

Zhang, U. and M. N. Toksöz, Nonlinear refraction travel time tomography, Geophysics, 63, 1726-1737, 1998.

Zhang, J., U.-S. Brink, and M. N. Toksöz, Nonlinear refraction and reflection travel time tomography, J. Geophys. Res., 103, 29743-29757, 1998.

S. Kodaira (e-mail: kodaira@jamstec.go.jp), T. Iidaka, A. Nakanishi, J.-O. Park, T. Iwasaki, and Y. Kaneda1 